BEATRIZ LAMEIRA CARRICO NIMER

\title{
CONSIDERAÇÕES SOBRE OS LIMITES CONSTITUCIONAIS DA FUNÇÃO JURISDICIONAL: ANÁLISE DO CONTEXTO BRASILEIRO PÓS-88
}

Tese de Doutorado

Orientador: Professor Associado Dr. Sérgio Resende de Barros

UNIVERSIDADE DE SÃO PAULO

FACULDADE DE DIREITO

SÃO PAULO-SP 



\section{CONSIDERAÇÕES SOBRE OS LIMITES CONSTITUCIONAIS DA FUNÇÃO JURISDICIONAL: ANÁLISE DO CONTEXTO BRASILEIRO PÓS-88}

Tese apresentada à Banca Examinadora do Programa de Pós-Graduação em Direito, da Faculdade de Direito da Universidade de São Paulo, como exigência parcial para a obtenção do título de Doutora em Direito, na área de concentração Direito do Estado, sob orientação do Professor Associado Dr. SÉRGIO RESENDE DE BARROS.

UNIVERSIDADE DE SÃO PAULO

FACULDADE DE DIREITO

SÃO PAULO-SP 
Autorizo a reprodução e a divulgação total ou parcial deste trabalho, por qualquer meio convencional ou eletrônico, para fins de estudo e de pesquisa, desde que citada a fonte.

Catalogação da Publicação

Serviço de Biblioteca e Documentação

Faculdade de Direito da Universidade de São Paulo

Nimer, Beatriz Lameira Carrico

Considerações sobre os Limites Constitucionais da Função Jurisdicional: Análise do Contexto Brasileiro Pós-88 / Beatriz Lameira Carrico Nimer ; orientador Sérgio Resende de Barros -- São Paulo, 2020.

$200 \mathrm{f}$.

Tese (Doutorado - Programa de Pós-Graduação em Direito do Estado) - Faculdade de Direito, Universidade de São Paulo, 2020.

1. 1. Limites constitucionais; 2. Atividade jurisdicional; 3. Decisões políticas; 4. Judicialização abrangente; 5. Estado de Direito. I. Barros, Sérgio Resende de, orient. II. Considerações sobre os Limites Constitucionais da Função Jurisdicional: Análise do Contexto Brasileiro Pós-88. 


\section{Folha de Aprovação}

NIMER, Beatriz Lameira Carrico. Considerações sobre os Limites Constitucionais da Função Jurisdicional: Análise do Contexto Brasileiro Pós-88. Tese apresentada à Faculdade de Direito da Universidade de São Paulo para a obtenção do título de Doutora em Direito do Estado, sob a orientação do Professor Associado Sérgio Resende de Barros.

\section{Aprovada em:}

\section{Banca Examinadora:}

Prof. Dr. Sérgio Resende de Barros

Julgamento:

Prof. Dr.

Julgamento:

Prof. Dr.

Julgamento:

Prof. Dr.

Julgamento:

Prof. Dr.

Julgamento:

Prof. Dr.

Julgamento:
Instituição: FDUSP

Assinatura:

Instituição:

Assinatura:

Instituição:

Assinatura:

Instituição:

Assinatura:

Instituição:

Assinatura:

Instituição:

Assinatura: 

A todos os meus familiares, inclusive os meus antepassados, em especial à memória de minha querida avó Francelina Carril Lameira e de meu querido bisavô Carlos Cassetari. 



\section{AGRADECIMENTOS}

De início, agradeço ao Professor Sérgio Resende de Barros, jurista notável e meu estimado orientador, que participou ativamente de minha formação jurídica e humanista, ensinando-me valiosas lições de vida, de moral e de Direito.

Agradeço, outrossim, aos Professores Rubens Beçak e Leonardo David Quintiliano, membros da banca de qualificação, que contribuíram de forma imprescindível para o desenvolvimento desta tese.

Também dedico profundo agradecimento à Professora Andreza A. de Souza Santos, que me acolheu no Centro de Estudos Latino-americanos da Universidade de Oxford e supervisionou minhas pesquisas acadêmicas no programa de doutoramento sanduíche que tive a honra de realizar no Reino Unido.

Por fim, destaco minha eterna gratidão aos meus pais e irmãs, que me acompanham diuturnamente e são parte indissociável da minha vida. 

Um dia, quando eu estava jantando sentado à mesa, um leigo que era conhecedor das leis de seu país estava lá. Seguindo uma observação ou outra, ele teceu comentários elaborados sobre a justiça que naquela época era aplicada aos ladrões na Inglaterra. Em todos os lugares eram vistas execuções, e às vezes até vinte eram dependurados na mesma forca. Ele falou que estava impressionado com a maldição que pairava sobre o país, com a proliferação de tantos ladrões em todos os lugares, mesmo com o rigor da justiça e com poucos que escapavam da punição legal. Eu, então, disse (e ousei me expressar livremente na presença do Cardeal): 'Você não deveria ficar surpreso. Pois essa punição é não apenas excessiva aos limites da justiça, como também não atende ao interesse público. Esse tipo de punição aos ladrões é muito severa, mas não serve para dissuadi-los: o furto simples não é um crime tão grave que mereça pena capital, e não há pena suficiente que impeça as pessoas de furtar quando não possuem outro meio de sobreviver. Então, em relação a isso, não apenas você, mas a maior parte do mundo tende a imitar os maus professores, que mais anseiam por bater nos alunos, do que por ensiná-los. Punições graves e horríveis são impostas aos ladrões, mas seria muito melhor prover-lhes a subsistência, a fim de que não padecessem da cruel necessidade de furtar e, depois, morrer por isso'.

(MORE, Thomas. Utopia. Livro I. New Haven \& London: Yale University Press, 2014, p. 18-9. Tradução livre). 



\section{RESUMO}

NIMER, Beatriz Lameira Carrico. Considerações sobre os limites constitucionais da função jurisdicional: análise do contexto brasileiro pós-88. f. Tese (Doutorado) Faculdade de Direito da Universidade de São Paulo, São Paulo, 2020.

A tese analisa os limites constitucionais impostos ao exercício da atividade jurisdicional. A justificação teórica parte das deficiências institucionais decorrentes de fatores históricos que culminaram com a ineficiência dos Poderes Executivo e Legislativo na tomada de diversas decisões políticas relevantes. Em meio a um cenário caótico, questões que poderiam ser resolvidas nas esferas de poder típicas para discipliná-las acabam sendo transferidas para o controle jurisdicional, identificando-se, nesse cenário, um fenômeno de judicialização abrangente. Assim, enquanto os outros poderes se mostram enfraquecidos ou acomodados, o Judiciário cresce em evidência, o que abre espaço para abusos e politização. Tomando como base os princípios que fundamentam o Estado de Direito - em contraponto às concepções de Estados de mera legalidade formal -, torna-se possível estabelecer os limites da atividade jurisdicional, que se norteiam pelas premissas da separação de poderes e do sistema de freios e contrapesos, bem como pelos direitos e garantias fundamentais, pela democracia, pela existência de um sistema de garantias da Magistratura e pela inafastável segurança jurídica.

Palavras chave: 1. Limites constitucionais; 2. Atividade jurisdicional; 3. Decisões políticas; 4. Judicialização abrangente; 5. Estado de Direito. 



\begin{abstract}
NIMER, Beatriz Lameira Carrico. Considerations on the constitutional boundaries to the judicial behaviour: post-88 scenario. _ f f. Thesis (PhD) - Faculty of Law of the University of São Paulo, São Paulo, 2020.

The thesis analyzes the constitutional boundaries to the judicial behaviour. The theoretical premise regards to the institutional deficiencies that result from a series of historical factors that caused the inefficiency of the Executive and Legislative branches in the decision-making process. In the midst of a chaotic scenario, political matters are transferred to jurisdictional control. Therefore, a phenomenon of comprehensive judicialization is identified. Thus, while the other branches are weakened or accommodated, the Judiciary grows in evidence, which leaves room for abuse and politicization. Based on the principles that underlie the rule of law - as opposed to the conceptions of states of mere formal legality - it becomes possible to establish the limits of judicial activity, which are guided by the premises of the separation of powers and the system of checks and balances, as well as fundamental rights, democracy, constitucional guarantees for the Judges, and the mandatory legal certainty.
\end{abstract}

Key words: 1. Constitutional boundaries; 2. Judicial behaviour; 3. Decision-making process; 4. Judicialization; 5. Rule of law. 



\section{RIASSUNTO}

NIMER, Beatriz Lameira Carrico. Considerazioni sui limiti costituzionali della funzione giurisdizionale: analisi del contesto brasiliano post-88. __ f. Tesi (Dottorato) - Facoltá di Diritto dela Università di São Paulo, São Paulo, 2020.

La tesi analizza i limiti costituzionali imposti all'esercizio dell'attività giudiziaria. La giustificazione teorica si basa su carenze istituzionali risultanti da una serie di fattori storici che sono culminati nell'inefficienza dei poteri esecutivo e legislativo nel prendere diverse decisioni politiche pertinenti. Nel mezzo di uno scenario caotico, i problemi che potrebbero essere risolti nelle sfere tipiche del potere per disciplinarli finiscono per essere trasferiti al controllo giurisdizionale, in cui viene identificato un fenomeno di giudiziarizzazione globale. Pertanto, mentre gli altri poteri sono indeboliti o accomodati, la magistratura cresce in evidenza, che apre lo spazio agli abusi e alla politicizzazione. Sulla base dei principi che sono alla base dello stato di diritto - al contrario delle concezioni degli stati di mera legalità formale - diventa possibile stabilire i limiti dell'attività giudiziaria, che sono guidati dalle premesse della separazione dei poteri e del sistema di freni e contrappesi, nonché per i diritti e le garanzie fondamentali, per la democrazia, per l'esistenza di un sistema di garanzie per la magistratura e per la sicurezza giuridica permanente.

Parole chiave: 1. Limiti costituzionali; 2. Attività giudiziaria; 3. Decisioni politiche; 4. Giudiziarizzazione; 5. Stato di diritto. 



\section{ABREVIATURAS E SIGLAS}

$\mathrm{AC}$

a.C.

ACP

ADCT

ADECON

ADI

ADPF

$\mathrm{Ag}$

$\mathrm{AgRg}$

AI

Ap.

ARE

art.

Câm.

Cív.

$\mathrm{CC}$

$\mathrm{CC} / 02$

$\mathrm{CC} / 16$

CDC

$\mathrm{CIDH}$

$\mathrm{CP}$

CPC-73

CPC-15

CRFB-88

d.C.

Des.

DF

Dir.

DJ

DJe
Apelação Cível

Antes de Cristo

Ação Civil Pública

Ato das Disposições Constitucionais Transitórias

Ação Declaratória de Constitucionalidade

Ação Direta de Inconstitucionalidade

Arguição de Descumprimento de Preceito Fundamental

Agravo

Agravo Regimental

Ato Institucional

Apelação

Agravo em Recurso Extraordinário

Artigo

Câmara

Cível

Código Civil

Código Civil de 2002

Código Civil de 1916

Código de Defesa do Consumidor

Corte Interamericana de Direitos Humanos

Código Penal

Código de Processo Civil

Código de Processo Civil de 2015

Constituição da República Federativa do Brasil de 1988

Depois de Cristo

Desembargador

Distrito Federal

Direito

Diário da Justiça

Diário da Justiça eletrônico 


\begin{tabular}{|c|c|}
\hline $\mathrm{EC}$ & Emenda à Constituição \\
\hline EDcl & Embargos de Declaração \\
\hline EUA & Estados Unidos da América \\
\hline FUNPEN & Fundo Penitenciário \\
\hline $\mathrm{HC}$ & Habeas Corpus \\
\hline IBGE & Instituto Brasileiro de Geografia e Estatística \\
\hline IF & Intervenção Federal \\
\hline inc. & Inciso \\
\hline $\mathrm{j}$. & Julgamento \\
\hline LACP & Lei da Ação Civil Pública \\
\hline LAP & Lei da Ação Popular \\
\hline LDO & Lei de Diretrizes Orçamentárias \\
\hline LIA & Lei de Improbidade Administrativa \\
\hline LINDB & Lei de Introdução às Normas do Direito Brasileiro \\
\hline MBL & Movimento Brasil Livre \\
\hline MDB & Movimento Democrático Brasileiro \\
\hline Min. & Ministro \\
\hline MPF & Ministério Público Federal \\
\hline MPSP & Ministério Público do Estado de São Paulo \\
\hline n. & Número \\
\hline $\mathrm{OAB}$ & Ordem dos Advogados do Brasil \\
\hline OSCIP & Organizações da Sociedade Civil de Interesse Público \\
\hline OS & Organizações Sociais \\
\hline p. & Página \\
\hline PSDB & Partido da Social Democracia Brasileira \\
\hline PT & Partido dos Trabalhadores \\
\hline $\mathrm{RE}$ & Recurso Extraordinário \\
\hline Rel. & Relator \\
\hline Resp. & Recurso Especial \\
\hline RISTF & Regimento Interno do Supremo Tribunal Federal \\
\hline RJ & Rio de Janeiro \\
\hline RJTJSP & Revista de Jurisprudência do Tribunal de Justiça de São Paulo \\
\hline RN & Rio Grande do Norte \\
\hline
\end{tabular}


Revista dos Tribunais

SP

São Paulo

STF

Supremo Tribunal Federal

STJ

Superior Tribunal de Justiça

TCE

Tribunal de Contas do Estado

TCU

Tribunal de Contas da União

TJSP

Tribunal de Justiça do Estado de São Paulo

TRE

Tribunal Regional Eleitoral

TSE

Tribunal Superior Eleitoral

USP

Universidade de São Paulo

$v s$.

Versus

v.u.

Votação unânime 



\section{SUMÁRIO}

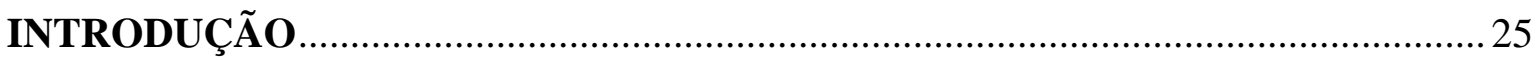

I.1. Justificação temática e contribuição da tese à Ciência Jurídica ..................................... 32

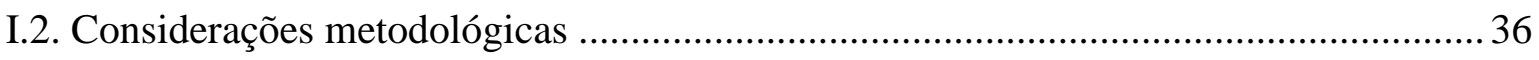

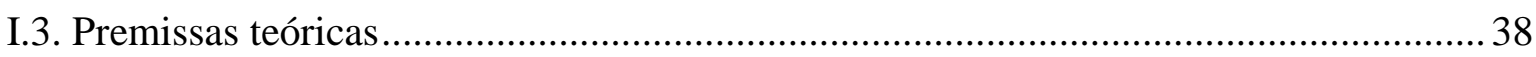

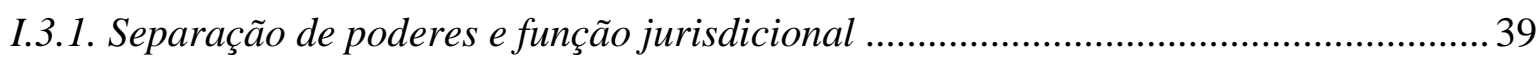

I.3.2. Classificação dos magistrados no rol de agentes públicos ......................................... 41

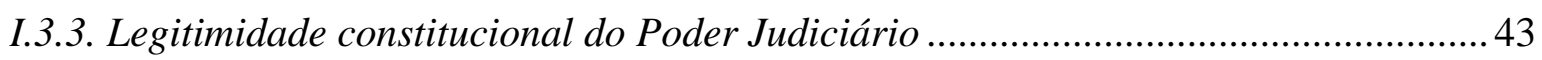

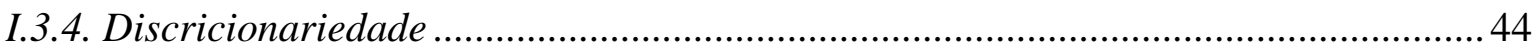

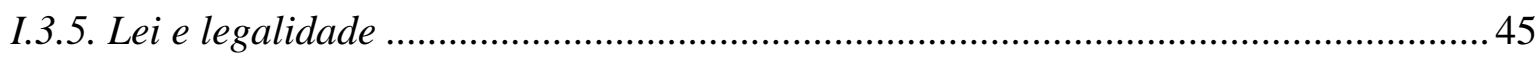

I.3.6. Sistemas jurídicos de tradição "common law”" e "civil law”................................... 46

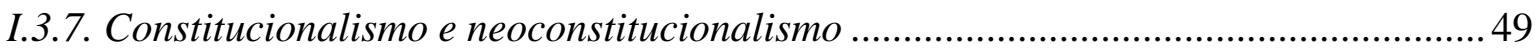

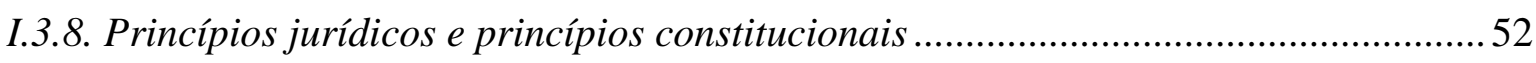

PARTE 1 - O PROTAGONISMO DO PODER JUDICIÁRIO NO PANORAMA POLÍTICO-INSTITUCIONAL BRASILEIRO........................................................... 54

1.1. A TRANSIÇÃO DE REGIMES: DA DITADURA MILITAR À

REDEMOCRATIZAÇÃO ....................................................................................... 56

1.2. O CENÁRIO DE CRISE DE LEGITIMIDADE DO PODER POLÍTICO NA NOVA

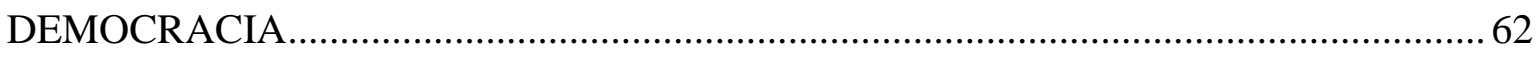

1.3. A ORDEM CONSTITUCIONAL PÓS-REDEMOCRATIZAÇÃO ................................

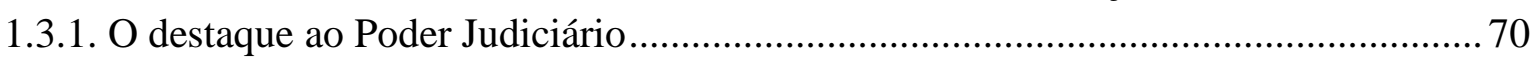

1.3.2. A proeminência da figura dos juízes..................................................................... 72

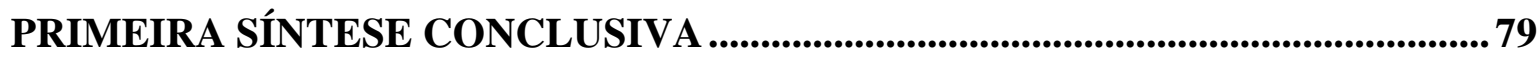

PARTE 2 - O PODER JUDICIÁRIO E A APLICAÇÃO DO DIREITO .................... 83

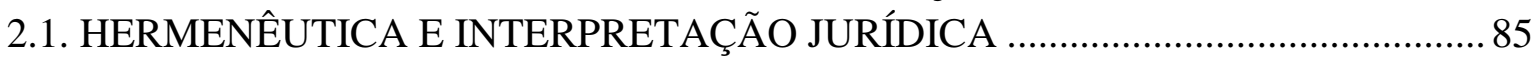

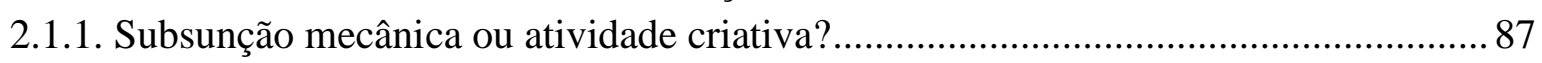

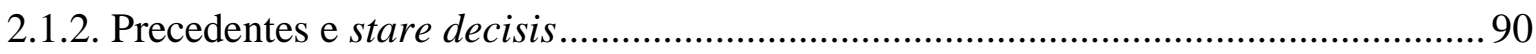

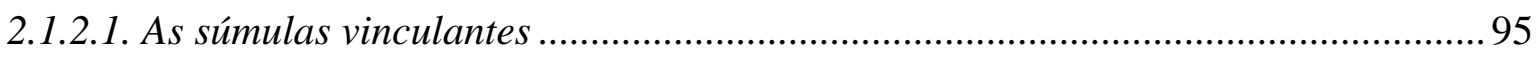

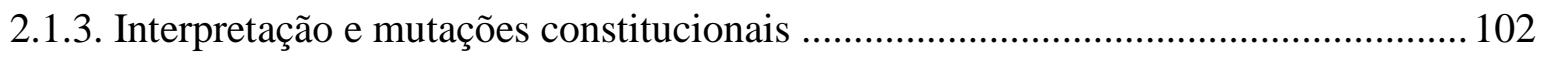

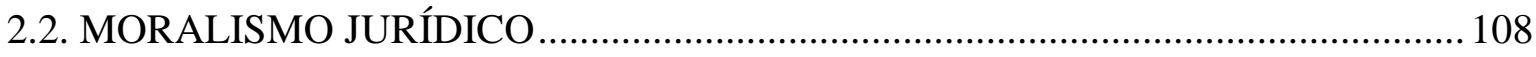

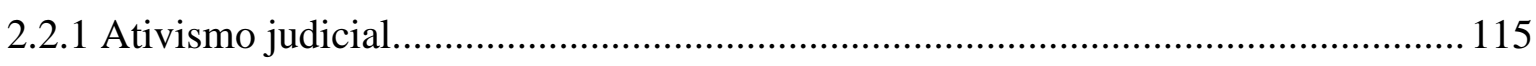

2.2.1.1. As decisões nos casos de valoração sensível ........................................................ 121

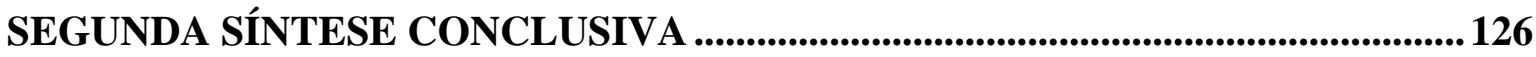


PARTE 3 - LIMITES IMPOSTOS PELO ESTADO DE DIREITO..........................129

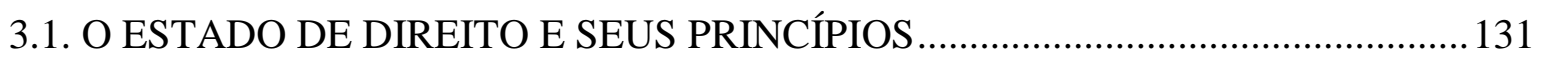

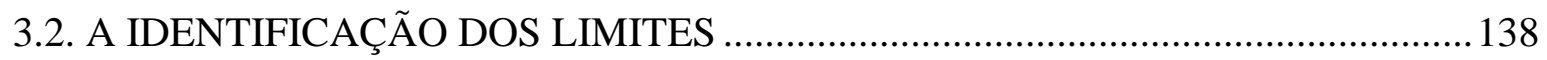

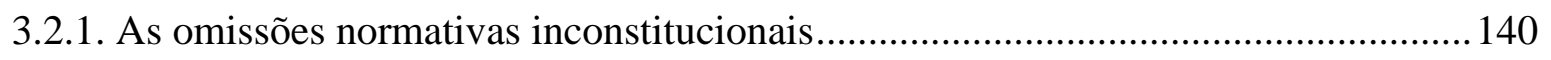

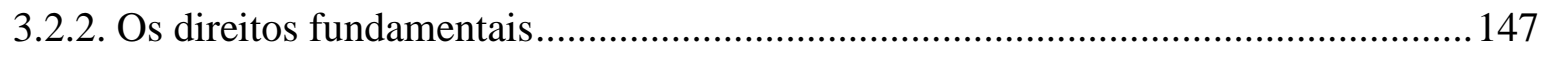

3.2.2.1. Os riscos da violação de direitos fundamentais a pretexto de protegê-los ...........159

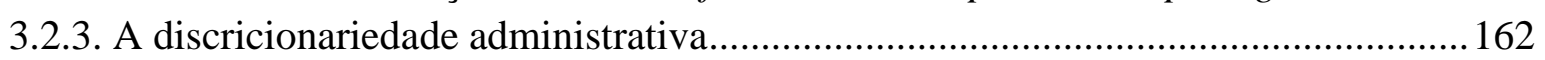

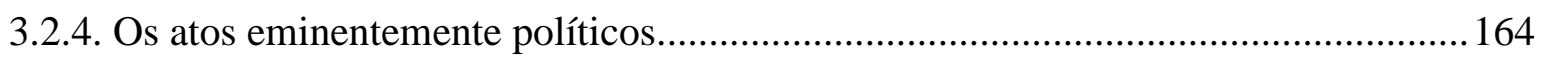

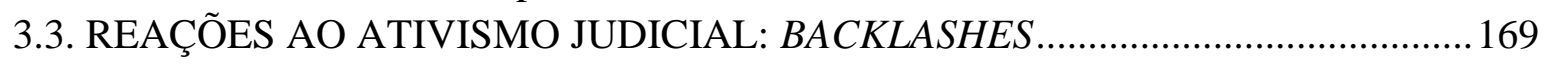

TERCEIRA SÍNTESE CONCLUSIVA ...............................................................................177

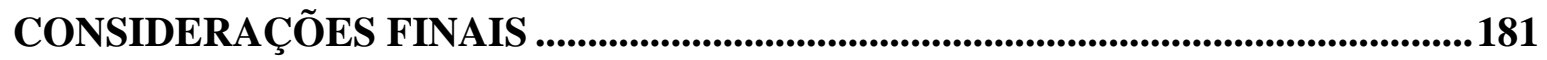

ÍNDICE DAS FONTES ..................................................................................................189

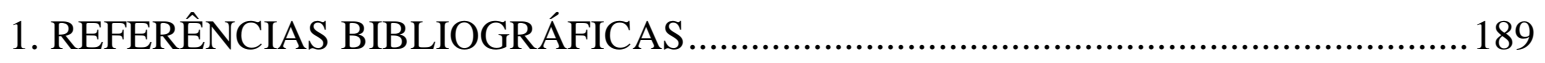

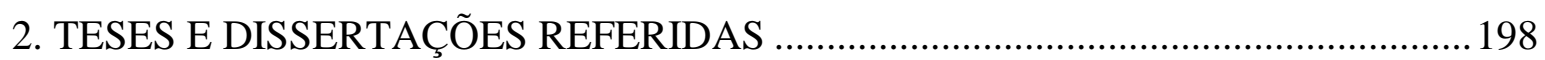

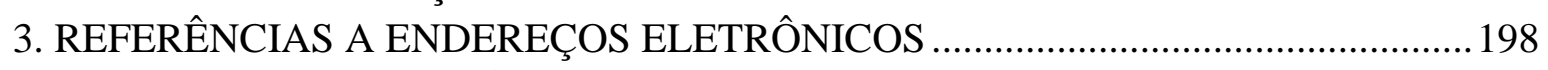

4. REFERÊNCIAS A MATÉRIAS JORNALÍSTICAS IMPRESSAS ............................200 


\section{INTRODUÇÃO}

Pela teoria da separação de poderes do Estado, verifica-se que o sistema constitucional reparte, entre diferentes órgãos, atribuições típicas que lhes individualizam e que são, via de regra, traduzidas em sua própria denominação. ${ }^{1}$ Partindo da doutrina de freios e contrapesos como premissa teórica para que haja bom funcionamento e interação entre as instituições estatais, o estudo ora desenvolvido analisa as restrições impostas pela Constituição Federal ao exercício da função jurisdicional. No atual cenário de protagonismo do Poder Judiciário em decorrência do enfraquecimento dos demais poderes frente ao descrédito popular e ao ceticismo quanto ao panorama político, a teoria constitucional deve ser analisada detidamente, com vistas à contenção de abusos e de distorções institucionais. Daí porque a função jurisdicional deve ser pautada pelas diretrizes do Estado de Direito, que impõe a observância das garantias dos cidadãos contra a tirania, a manutenção da ordem pública, a segurança jurídica, a separação de poderes e o regime democrático.

No Brasil, a CF-88, em seu art. $2^{\circ}$, elenca os Poderes Executivo, Legislativo e Judiciário, todos independentes e harmônicos entre si, ostentando, cada um, respectivamente, as seguintes funções precípuas: função administrativa (que consiste, em síntese, na conversão da lei em ato individual e concreto) ${ }^{2}$, função normativa (elaboração das leis) e função jurisdicional. Esta última servirá de lastro à delimitação do tema ora proposto, traduzindo-se, pois, na seguinte definição:

\footnotetext{
Função jurisdicional é a função que o Estado, e somente ele, exerce por via de decisões que resolvem controvérsias com força de "coisa julgada", atributo este que corresponde à decisão proferida em última instância pelo Judiciário e que é predicado desfrutado por qualquer sentença ou acórdão contra o qual não tenha havido tempestivo recurso. ${ }^{3}$
}

\footnotetext{
${ }^{1}$ José Afonso da Silva salienta que cada órgão representativo da divisão de poderes do Estado recebe o nome da própria função que o caracteriza, com exceção do Judiciário, que exerce função jurisdicional. Nesse sentido: “(...) A distinção de funções constitui especialização de tarefas governamentais à vista de sua natureza, sem considerar os órgãos que as exercem; quer dizer que existe sempre distinção de funções, quer haja órgãos especializados para cumprir cada uma delas, quer estejam concentradas num órgão apenas. A divisão de poderes consiste em confiar cada uma das funções governamentais (legislativa, executiva e jurisdicional) a órgãos diferentes, que tomam os nomes das respectivas funções, menos o Judiciário (órgão ou poder Legislativo, órgão ou poder Executivo e órgão ou poder Judiciário)" (SILVA, José Afonso da. Curso de Direito Constitucional Positivo. 30. ed. São Paulo: Malheiros, 2008, p. 108).

${ }^{2}$ Cf. MEIRELLES, Hely Lopes. Direito Administrativo Brasileiro. 34. ed. São Paulo: Malheiros, 2008, p. 61. ${ }^{3}$ BANDEIRA DE MELlO, Celso Antônio. Curso de Direito Administrativo. 33. ed. São Paulo: Malheiros, 2016 , p. 36.
} 
Distingue-se, nesse viés, a função jurisdicional da chamada função judicial, sendo certo que esta última engloba não apenas os atos tipicamente jurisdicionais, mas também todas as demais atividades exercidas no bloco orgânico do Poder Judiciário, abarcando suas funções atípicas de naturezas administrativa ou legislativa.

Em Constituições anteriores, previa-se uma divisão rígida de Poderes, vedando-se, em larga escala, a delegação de atribuições a outros órgãos funcionais. ${ }^{4} \mathrm{Na}$ atual ordem constitucional, porém, evidencia-se a possibilidade de, além do exercício de suas funções típicas, cada aparato organizacional de Poder também exercer, de maneira atípica, funções inerentes aos outros Poderes. Alguns exemplos podem ser extraídos do texto constitucional expresso, a saber: permissão de que Deputados e Senadores (membros do Poder Legislativo) exerçam funções de Ministro de Estado, de Secretário de Estado, do Distrito Federal, de Prefeitura de Capital ou de missão diplomática temporária (ligados ao Poder Executivo), nos termos do art. 56 da CF-88; adoção, pelo Presidente da República, de medidas provisórias com força de lei (art. 62 da CF-88); e autorização de delegação de atribuições legislativas ao Presidente da República (art. 68 da CF-88). Além disso, exemplos como o de julgamento de crimes de responsabilidade no âmbito do Poder Legislativo e o julgamento de processos administrativos perante a Administração Pública (Poder Executivo) são hipóteses de exercício de função mais atrelada ao que seria jurisdicional do que legislativa e administrativa.

Para os fins a que se destina o presente estudo, a função jurisdicional deve ser entendida em sua dimensão típica exercida pelo Poder Judiciário, enquanto órgão que a realiza por meio de decisões proferidas em última instância, com força de coisa julgada podendo, inclusive, rever as decisões do Legislativo proferidas nos julgamentos dos crimes de responsabilidade, e do Executivo nos processos administrativos, ao menos com base em critérios de legalidade formal (devido processo legal).

A proposição aqui tratada reside, portanto, nos limites constitucionais à atuação do Poder Judiciário no exercício de sua função típica jurisdicional.

${ }^{4}$ Cf. SILVA, José Afonso da. Curso de Direito Constitucional Positivo... op. cit., p. 111. 
O problema proposto já tem sido objeto de estudos da doutrina constitucional e sua importância parece crescer na mesma proporção em que se manifesta a atuação cada vez mais enfática do Poder Judiciário no cenário institucional brasileiro.

O início da discussão ora estabelecida remonta à concepção da doutrina de freios que contrapesos, que pressupõe inegáveis interferências entre os órgãos de Poder, com vistas ao equilíbrio necessário para a realização do bem comum e para evitar o arbítrio de um em relação ao outro. Quando, porém, a atuação harmônica entre os Poderes se abala - por motivos de ordem histórica, social, econômica ou política -, acaba por emergir o predomínio de um frente aos demais, quebrando-se o equilíbrio que deveria ser mantido.

Isso ocorre em virtude de deficiências sistêmicas. Assim, quando o Legislativo e o Executivo se enfraquecem - quer por descrédito popular, quer por falhas internas de sua expressão política -, tende a se manifestar, talvez de maneira natural, o protagonismo do Poder Judiciário.

O estudo parte, então, da premissa de que esse protagonismo do Judiciário não é a fonte geradora da debilidade das instituições de Poder, mas decorre do enfraquecimento dos demais poderes e da necessidade de o Estado se fazer presente para regular a vida em sociedade. Em um modelo sadio, cada órgão de poder deveria ter a sua atuação bem delimitada e exercida de maneira forte, com natural destaque inerente a cada uma das típicas esferas de atribuições. Porém, em modelos debilitados, a ausência de atuação estatal em uma de suas frentes de Poder acaba sendo suprida por outra que possua maior margem de incisão social. E é daí, portanto, que acaba por emergir o destaque do Poder Judiciário.

Dotado da capacidade de resolver conflitos de interesses com força de coisa julgada, aplicando a lei ao caso concreto, e evidenciando-se o Supremo Tribunal Federal como intérprete máximo da Constituição, a massiva gama de mazelas sociais acaba por ser dirigida ao Poder Judiciário por meio de ações judiciais (processos) no bojo das quais há de ser proferida uma decisão que lhes ponha um termo final - quer pela resolução do mérito, quer pela extinção por motivos formais de ordem processual.

Nos casos em que há lei reguladora do conflito de interesses e em que a atuação jurisdicional não encontra embaraços nas funções típicas dos demais poderes, parece não haver dúvidas de que inexiste hipótese de protagonismo atípico ou disfuncional. Porém, quando a situação submetida à apreciação do Poder Judiciário resvala em situações inerentes 
às funções típicas dos outros Poderes, emerge a necessidade de perquirição dos limites constitucionais ao exercício da jurisdição.

Muitos exemplos podem ser trazidos para fins de elucidação, os quais são apresentados no corpo do trabalho por meio da análise de julgados, considerando-se, sempre, que o interesse maior da investigação reside na demarcação mais abrangente da esfera de desenvolvimento da função jurisdicional, com enfoque para a sua legitimidade constitucional 5 .

Um exemplo marcante diz respeito ao chamado estado de coisas inconstitucional, ou seja, à teoria originária da Corte Constitucional da Colômbia de que a inconstitucionalidade pode se verificar - e ser declarada pelo Poder Judiciário - sempre que ocorrer massiva violação fática de direitos fundamentais, decorrente de falhas estruturais do aparato estatal e da falência de políticas públicas destinadas a determinado setor. Ou seja: trata-se de decorrência da omissão ou negligência do Poder Público (mormente das esferas de atuação política) em relação a determinado setor ou situação que demanda sua eficaz atuação.

Mas, além da análise da atuação do Poder Judiciário frente a hipóteses de estados de coisas inconstitucionais que tenham sido submetidas à sua apreciação, o trabalho analisa outros casos polêmicos em que a jurisdição se manifesta, principalmente quando há inércia ou omissão dos demais Poderes.

Nesse contexto, é importante, desde já, ressaltar que o estado de coisas inconstitucional não se confunde com as hipóteses típicas de omissão legislativa inconstitucional. A Constituição possui normas que dependem de regulamentação para que o direito nelas impresso possa ser efetivado. Assim, configura-se a omissão legislativa inconstitucional quando estão presentes os seguintes pressupostos: a) obrigação de legislar prevista constitucionalmente; b) ausência de lei regulamentadora ou insuficiência da medida tomada pelo legislador; c) esgotamento do prazo constitucionalmente previsto para a ação

\footnotetext{
${ }^{5}$ Destaque-se, desde já, que o porquê da utilização da expressão "legitimidade constitucional" será melhor explanado no item "5" (Metodologia utilizada). Por ora, deve-se mencionar, apenas, que o enfoque da tese não residirá na aferição da legitimidade democrática do Poder Judiciário, por se entender que esse tema é afeto à Ciência Política. No campo da Ciência do Direito, o interesse que predomina é o da aferição da legitimidade desse Poder - e, consequentemente, dos limites à sua atuação - à luz da Constituição. Daí o uso da expressão "legitimidade constitucional".
} 
legislativa, ou fluência de prazo superior ao razoável para que o legislador adote as medidas necessárias à efetivação da norma constitucional. ${ }^{6}$

Quando, porém, se está diante de situação em que não existia uma obrigação de legislar especificamente constante da Constituição Federal, mas sim um dever genérico de garantia dos princípios constitucionais típicos - traduzidos em objetivos e fundamentos da República, bem como em direitos fundamentais -, a negligência ou omissão do Poder Público não configuram uma omissão legislativa inconstitucional propriamente dita, mas sim um estado de coisas inconstitucional, que pode ser ocasionado por falhas não apenas do Poder Legislativo, mas também do Poder Executivo.

Diante de situações como essa, advém a indagação: o Poder Judiciário, quando instado a se manifestar em casos desse jaez, possui legitimidade constitucional para emitir comandos ao legislador e à Administração Pública? A resposta demanda a análise dos limites que a Constituição Federal impõe a essa atuação. Desrespeitadas as balizas constitucionais do Estado de Direito, a atuação jurisdicional importa indevida imissão em seara reservada aos demais Poderes.

Também se devem analisar os limites da função jurisdicional frente a hipóteses em que não há omissão dos demais Poderes. Até que ponto pode o Judiciário, por exemplo, adentrar no mérito de atos administrativos ou legislativos, com vistas a avaliá-los à luz de casos concretos, ou de controle abstrato de constitucionalidade? A questão assume relevo em decorrência da teoria do desvio de poder nos atos administrativos, em suas dimensões de excesso de poder e desvio de finalidade, e na cláusula do devido processo legal em sua dimensão material (ou substantiva), a ser aplicada no âmbito do processo legislativo.

Delineados tais contornos, o trabalho ainda enfrenta os conceitos de ativismo judicial e de judicialização da política, e se existem fundamentos constitucionais para a intervenção do Poder Judiciário no processo político.

\footnotetext{
${ }^{6}$ Cf. RAMOS, Luciana de Oliveira. O Controle de Constitucionalidade por Omissão no Supremo Tribunal Federal: Análise dos Casos de Omissão Legislativa nos Vinte e Um Anos da Constituição. $2010.135 \mathrm{f}$. Dissertação (Mestrado em Ciência Política). Faculdade de Filosofia, Letras e Ciências Humanas da Universidade de São Paulo, São Paulo, 2010, p. 20. Acerca do tema, confira-se ainda: SOUZA, Luiz Herique Boselli de. A correlação da efetividade das normas constitucionais com o suprimento das omissões normativas. 2010. 226 f. Tese (Doutorado). Faculdade de Direito da Universidade de São Paulo, São Paulo, 2010.
} 
Também se dá destaque às reações dos demais poderes frente ao protagonismo do Judiciário e à sua postura "ativista". Quanto a isso, o estudo adentra no fenômeno denominado backlash, que se volta à contra-mobilização das instituições, em resposta normal a demandas públicas desfavoráveis à atuação judicial em determinados setores, especificamente quando são proferidas decisões que afetam a esfera política e acabam por desagradar os anseios populares.

Como já ressaltado, o tema é desenvolvido sob uma perspectiva constitucional. Inegavelmente, é necessário tecer considerações, em algumas oportunidades, que espraiam sobre campos de cunho político, filosófico ou sociológico; mas apenas de forma tangencial e ilustrativa, inexistindo a pretensão de se adentrar no estudo dessas ciências, que não são jurídicas.

Em suma, o que se pôde verificar, pelos estudos desenvolvidos, é que os limites constitucionais da função jurisdicional são traçados não apenas no Capítulo III da Constituição Federal, que regula estruturalmente o Poder Judiciário, mas também, e principalmente, nos seguintes parâmetros básicos: (a) o art. $2^{\circ}$, que dispõe sobre a divisão, independência e harmonia entre os Poderes, do qual decorre o sistema de freios e contrapesos; (b) o pré-compromisso constitucional de agir, cujos parâmetros residem nos fundamentos, objetivos e princípios da República Federativa do Brasil (arts. $1^{\circ}, 3^{\circ}$ e $4^{\circ}$, respectivamente); e (c) os direitos e garantias fundamentais (arts. $5^{\circ}$ e $6^{\circ}$ ), em especial a previsão do art. $5^{\circ}, \mathrm{XXXV}$, que consubstancia o princípio da inafastabilidade da jurisdição frente a lesão ou ameaça de lesão a direitos.

Ou seja: a efetivação dos direitos fundamentais - em especial na dimensão dos direitos sociais, que são direitos humanos de segunda geração - demanda um agir do Estado no sentido de atitude positiva de sua implementação e realização. Quando há inércia dos Poderes Públicos, impõe-se a intervenção supletiva do Poder Judiciário. Tal intervenção, porém, é restrita aos limites do dirigismo constitucional, cuja aferição está atrelada aos parâmetros político-jurídicos que marcaram as escolhas programáticas contidas no texto constitucional (no sentido de programas a serem desenvolvidos por meio de políticas 
públicas), bem como a critérios visualizáveis na realidade social concreta: possibilidade financeira do Estado e garantia das condições mínimas de vida material aos cidadãos. ${ }^{7}$

É fácil utilizar o exemplo dos direitos fundamentais sociais porque, por demandarem uma atuação positiva do Estado, acabam sendo judicializados quando da inércia dos demais poderes, o que enseja a tomada de decisões pelo Poder Judiciário que, ao menos, tangenciam escolhas que primordialmente deveriam ser políticas (e não puramente jurídicas).

E, de todo o exposto, o cerne é o seguinte: o Poder Judiciário é, por natureza, inerte e deve ser instado a agir. Isso só ocorre quando há lesão ou ameaça a direito, tanto no âmbito privado, quanto no público. Se alguma questão envolve a tomada de decisões que são inerentes às funções típicas do Executivo ou do Legislativo, isso pode abalar a estrutura da divisão dos Poderes. Mas, por se tratar de instância que detém o dever de dizer o Direito no caso concreto, com força de definitividade, torna-se difícil, a priori, identificar quem o controla - haja vista que, na maioria das vezes, o Judiciário parece ser o controlador dos demais Poderes. Então, quem controla o controlador? A resposta reside no consectário do princípio da separação de Poderes, ou seja, no sistema de freios e contrapesos: assim como o Judiciário tem o dever de declarar a inconstitucionalidade de leis que violem a Lei Maior e de julgar a constitucionalidade e a legalidade da atuação administrativa, inclusive atribuindo solução jurídica às hipóteses de omissão governamental, incumbe ao Executivo e ao Legislativo, dentro das especificidades de suas esferas de atribuição, a tomada das medidas necessárias para conter eventuais arbítrios jurisdicionais, a fim de que se garanta uma ordem harmônica prevista no art. $2^{\circ}$ da CRFB-88. Daí decorrem os exemplos citados anteriormente, relativos aos efeitos backlash e às reações legislativas ao ativismo judicial.

E toda essa estrutura é consequência do Estado de Direito, ou seja, do modelo de Estado em que predomina a justiça substancial - e não a mera legalidade formal -, com a harmonia entre os poderes, que está intimamente relacionada à efetiva garantia dos direitos fundamentais, da segurança jurídica e do regime democrático.

\footnotetext{
${ }^{7}$ A propósito, cf. ALMEIDA, Luiz Eduardo de. Direitos sociais e seus limites - Uma construção a partir das decisões do STF. Curitiba: Juruá, 2017.
} 


\section{I.1. Justificação temática e contribuição da tese à Ciência Jurídica}

O Poder Judiciário tem exercido papel ativo na vida institucional brasileira. Isso se evidencia pelo fenômeno da judicialização crescente, em virtude do qual questões de repercussão política e social têm sido decididas no âmbito jurisdicional e não em meio às instâncias políticas tradicionais (Poder Legislativo e Poder Executivo).

Tal fenômeno da judicialização, que se caracteriza pela transferência de poder político para a Magistratura, gera consequências sensíveis no campo da linguagem, da argumentação e no modo de participação da sociedade na tomada de decisões que lhe interessam diretamente.

Dentre as causas que concorrem para a crescente judicialização das questões políticas, destacam-se a redemocratização do país - com o advento da Constituição da República Federativa do Brasil de 1988 - e a constitucionalização abrangente. Por certo, a recuperação das garantias da Magistratura, o restabelecimento da democracia, o renascimento do ideário de cidadania, o clamor por justiça e a expansão institucional do Ministério Público e da Defensoria Pública contribuíram para o fortalecimento do Poder Judiciário e para o consequente aumento das demandas judiciais.

Além disso, as crises econômicas e a corrupção marcam um cenário de ineficácia dos modos convencionais de articulação social e de esvaziamento dos modelos socialdemocratas de transformação política, com consequente descrença nos instrumentos e nas possibilidades da política em si. Nesse vácuo deixado pelo amesquinhamento do setor político, emergiu o protagonismo judicial, com a ampliação da jurisdição conforme sistemas normativos nos quais princípios se sobrepõem a regras. ${ }^{8}$ Essa tendência inerente ao chamado “pós-positivismo" preconiza a interpretação principiológica extensiva, inclusive com base em valores de cunho moral. Quando isso ocorre, perde-se, sobremaneira, em segurança jurídica, dada a relatividade da moral, que é imanente. Daí porque o exercício da jurisdição “moral” há de ser, necessariamente, questionado pela Ciência do Direito. 9

\footnotetext{
${ }^{8}$ Cf. FARIA, José Eduardo. Políticos e juízes, entre o destino e a tragédia. O Estado de São Paulo. São Paulo, 25 jun. 2018. Espaço Aberto, p. A2.

${ }^{9}$ A noção de Ciência do Direito aqui referida é a de um Direito positivado no espaço e no tempo. Nesse sentido, explica Miguel Reale: “A Ciência do Direito é sempre ciência de um Direito positivo, isto é, positivado no
} 
Ao mesmo tempo, a incorporação, no texto constitucional, de matérias que antes eram disciplinadas apenas em legislação ordinária - espectro da constitucionalização abrangente, decorrente das tendências atreladas ao denominado "neoconstitucionalismo" também gerou o aumento da atuação do Poder Judiciário. Em verdade, Constituição analítica como a brasileira, que contém disciplinamento vasto acerca de inúmeras matérias, cria uma série de direitos e lhes garante instrumentos hábeis à sua consecução.

Em outras palavras: sempre que uma determinada matéria é alçada ao patamar de norma constitucional, ela se transforma potencialmente em pretensão jurídica e, como tal, pode ser formulada sob a configuração de ação judicial. Essa judicialização de direitos gera a possibilidade de ser levado à apreciação do Poder Judiciário o debate sobre ações concretas ou políticas públicas, instando-se a Magistratura a se manifestar não apenas sobre conflitos de interesses intersubjetivos, mas até mesmo sobre a atuação ou omissão dos demais Poderes do Estado.

Some-se ao quanto foi dito até agora que o sistema brasileiro de controle de constitucionalidade é extremamente abrangente e, como tal, admite que quase qualquer questão política ou moralmente relevante possa ser alçada ao julgamento do STF. ${ }^{10}$ Neste ponto, esclareça-se que se adota, no Brasil, um sistema de origem híbrida, que colheu elementos europeus e americanos. Da fórmula americana de controle de constitucionalidade, o aparelho brasileiro adotou a possibilidade de se realizar o controle incidental e difuso, por meio do qual qualquer Juiz ou Tribunal pode deixar de aplicar a lei ao caso concreto que lhe seja levado à apreciação, por considerá-la inconstitucional. Do modelo europeu, por seu turno, adveio o controle concentrado, através de ações diretas e específicas para essa finalidade. Acresça-se a isso o amplo rol de legitimados ativos para a propositura de ação direta de inconstitucionalidade e ação declaratória de constitucionalidade, previsto no art. 103 da CRFB-88, a englobar o Presidente da República, a Mesa do Senado Federal, a Mesa da Câmara dos Deputados, a Mesa da Assembleia Legislativa ou da Câmara Legislativa do Distrito Federal, o Governador de Estado ou do Distrito Federal, o Procurador-Geral da República, o Conselho Federal da Ordem dos Advogados do Brasil, os partidos políticos

espaço e no tempo, como experiência efetiva, passada ou atual. Assim é que o Direito dos gregos antigos pode ser objeto de ciência, tanto como o da Grécia de nossos dias. Não há, em suma, Ciência do Direito em abstrato, isto é, sem referência direta a um campo de experiência social. Isto não significa, todavia, que, ao estudarmos as leis vigentes e eficazes no Brasil ou na Itália, não devamos estar fundados em princípios gerais comuns, produto de uma experiência histórica que tem as mesmas raízes, as do Direito Romano" (REALE, Miguel. Lições preliminares de Direito. São Paulo: Saraiva, 2007, p. 17).

${ }^{10}$ Idem, p. 74. 
com representação no Congresso Nacional e as confederações sindicais ou entidades de classe de âmbito nacional.

Nos últimos anos, têm sido decididas pelo STF, em sede de ações constitucionais que englobam ação direta de inconstitucionalidade (ADI), ação declaratória de constitucionalidade (ADC), ação direta de inconstitucionalidade por omissão (ADO) e arguição de descumprimento de preceito fundamental (ADPF) -, inúmeras questões de relevância pública que versam sobre as mais diversas pretensões jurídicas garantidas pela Constituição, inclusive com reflexos não apenas jurídicos, mas também políticos.

Além disso, têm sido constantes as ações judiciais individuais em que se pleiteia a garantia de direitos que, apesar de no caso concreto pertencerem a pessoas particularizadas, acabam por surtir os chamados "efeitos sistêmicos". Ou seja: a realização da microjustiça (justiça no caso concreto) pode, por vezes, ter consequências imprevisíveis e indesejadas, impactando sobre a realidade de determinado segmento econômico, ou sobre a prestação de políticas públicas. Elucidativos são os casos de mandados de segurança ou ações de rito comum em matérias de saúde ou de educação: a garantia, para casos concretos e individualizados, do fornecimento de medicamentos e tratamentos de saúde a pessoas hipossuficientes, ou a reserva de vagas em creches ou escolas públicas aos necessitados, são exemplos de intervenções judiciais que, não obstante necessárias e meritórias, acabam por se chocar com o aparato organizacional administrativo relativo à prestação de serviços e estruturação de políticas públicas. A necessidade de realocação de recursos públicos para fins não previamente idealizados em virtude de comandos do Poder Judiciário surte reflexos sobre as funções legislativa e executiva.

A judicialização e o ativismo judicial têm sido, portanto, fenômenos recorrentes na história jurídica atual do país. Em setembro de 2015, foi julgada a já mencionada ADPF 347, em sede da qual o Supremo Tribunal Federal incorporou à jurisprudência pátria a teoria do estado de coisas inconstitucional, originalmente concebida pela Corte Constitucional da Colômbia. Trata-se de situação em que o Poder Judiciário declarou que um "estado de coisas" era inconstitucional, indo além de sua competência para invalidar leis ou atos normativos pela via do controle de constitucionalidade.

Nessas situações, que possuem forte impacto sobre a separação das funções do Estado e ocasionam, inclusive, dispêndios financeiros não previstos em planejamento 
orçamentário, urge perquirir se a atuação do Poder Judiciário está acobertada por legitimidade democrática, ou se tamanha judicialização transborda os limites traçados pela Constituição Federal.

Em meio a esse cenário, as reações da sociedade civil e dos demais Poderes - em especial do Legislativo, com a edição de leis que visam traçar balizas contra o arbítrio judicial - têm ganhado relevo no cenário atual. Isso se torna visível não apenas por meio dos instrumentos tradicionais de obtenção de informações (jornais diários, rádio, televisão e pesquisa in loco), mas especialmente, na atualidade, pelas redes sociais, que são espaços virtuais onde qualquer pessoa pode externar suas opiniões e nos quais têm se avolumado críticas à má atuação estatal em todas as suas esferas, tanto no âmbito político, quanto no jurisdicional.

O tema em questão, por conseguinte, é de extrema importância doutrinária para o Direito, possuindo contornos, abrangência e delimitações essenciais à análise da fenomenologia jurídico-constitucional.

A abordagem ora proposta parte do pressuposto de que o ativismo judicial só ocorre quando já está instalada uma crise no sistema de separação de Poderes. A ascensão do Judiciário nada mais é do que decorrência do passivismo do Executivo e do Legislativo. E isso deriva do princípio constitucional da inafastabilidade da jurisdição (art. $5^{\circ}, \mathrm{XXXV}$, da CRFB-88-88), atrelado compromisso constitucional de aplicabilidade imediata dos direitos fundamentais.

Ou seja: o Poder Judiciário só se manifesta quando instado a agir, em decorrência da inércia típica da jurisdição. Portanto, inexiste verdadeira possibilidade de se atribuir caráter "ditatorial" a esse Poder, uma vez que sua atuação jamais será impositiva ou coercitiva, senão nos limites da coisa julgada, após a provocação das partes interessadas.

Mas, como já dito à exaustão, determinadas decisões judiciais adentram em questões que são típicas da esfera de atribuição de outros poderes, o que caracteriza uma postura ativista. Isso, ressalte-se, decorre de falhas sistêmicas e estruturais: não houvesse a omissão ou a deficiência na implementação das medidas inerentes ao Executivo e ao Legislativo, o Judiciário não teria sido instado a agir para suprir as lacunas ou para solucionar hipóteses de lesão ou ameaça de lesão a direitos. 
Por isso, o foco da tese não é a análise do ativismo judicial em si, como objeto principal de estudo, e nem tampouco atribuí-lo exclusivamente a uma postura abusiva da Magistratura. Discorre-se sobre esse assunto incidentalmente, dando-se ênfase aos limites constitucionais da função jurisdicional, ou seja, aos parâmetros que autorizam a margem decisória pelo Poder Judiciário.

O núcleo teórico reside na aferição dos limites da atividade jurisdicional a partir dos consectários do Estado de Direito, em especial: as garantias dos cidadãos contra os abusos de Poder do Estado, a manutenção da ordem pública, a segurança jurídica e o princípio da separação de Poderes, que é garantidor do regime democrático. Desse modo, se a atuação jurisdicional resvala em ilegalidade, abuso de poder, desrespeito à ordem pública, insegurança jurídica ou violação às funções típicas dos demais Poderes, haverá inegável transgressão aos limites constitucionais de sua atuação.

O segundo ponto, por seu turno, reside na análise das reações sistêmicas ao ativismo judicial ou à violação aos mencionados limites. Muito se fala sobre o ativismo, mas a doutrina brasileira pouco aborda as reações a esse fenômeno, motivo pelo qual o estudo aborda sobre a forma como o mecanismo de freios e contrapesos é capaz de, naturalmente, conter os abusos de um Poder frente aos demais, tudo com vistas à manutenção da harmonia prevista no art. $2^{\circ}$, caput, da CRFB-88. São estudados os fenômenos práticos dessa questão, em especial as atividades legislativas reativas e os efeitos backlash visualizáveis no ambiente social.

\section{I.2. Considerações metodológicas}

Quando o pesquisador se põe a desenvolver uma tese, deve ter em mente a necessidade de adotar um método de estudo, sob pena de desviar-se dos caminhos exigidos pelo rigor científico. O método deve ser entendido, portanto, como o caminho que se percorre para a aquisição da verdade, ou seja, de um resultado exato ou, ao menos, rigorosamente verificado; não há ciência sem método.

A primeira observação metodológica a ser feita é no sentido de que, por se tratar de tese de Direito Constitucional, o seu desenvolvimento se deu à luz da Ciência do Direito. 
Pode parecer uma obviedade, mas o que se quer esclarecer, desde logo, é que não se pretende adentrar nos meandros específicos de outras ciências, tais como a Política, a Filosofia ou a Sociologia.

Em virtude das inegáveis repercussões do tema sobre essas ciências, que já ensejaram estudos nessas específicas áreas, foram feitos apontamentos, no decorrer da tese desenvolvida, que tangenciam ramos do conhecimento diversos do Direito. Todavia, considerações desse jaez são meramente pontuais e exemplificativos, de modo que o foco científico é sempre jurídico.

O objeto da reflexão é o Direito no pensamento dogmático, tendo como ponto de partida e enfoque principal a Constituição Federal. Mas a análise propriamente dita não é puramente dogmática, haja vista a necessidade de utilização do método zetético para o bom desenvolvimento do tema.

Acerca da diferenciação entre os métodos dogmático e zetético, vale ponderar, sinteticamente, que o primeiro procura compreender o Direito e torná-lo aplicável dentro dos marcos da ordem jurídica, partindo de certas premissas vinculantes para o estudo (dogmas). A zetética, por outro lado, admite um amplo campo de investigações do fenômeno jurídico, podendo se dividir em zetética empírica e em zetética analítica. $\mathrm{O}$ empirismo permite que a investigação se realize nos limites da experiência, ou que os ultrapasse, atingindo a lógica formal, a teoria do conhecimento ou a metafísica. A especulação analítica, por outro lado, pode gerar como resultado a aplicação técnica à realidade. Assim, quando um estudo parte do plano da lógica das prescrições, indagando a Constituição quanto ao seu caráter de norma primeira e fundamental, o método utilizado é o da zetética analítica. Quando, por outro lado, se pretende conhecer como as Constituições atuam nas searas social, histórica, política e econômica, por meio da experiência concreta, a abordagem se dá pela zetética empírica. Ademais, a investigação por ter um viés de zetética pura ou aplicada, a depender da motivação da análise: se estiver correlacionada à aplicabilidade prática das prescrições estudadas, o método zetético será o aplicado; se, porém, o estudo for meramente teórico, haverá enfoque zetético puro.

Destarte, para fins da tese proposta, extraíram-se da zetética empírica pura elementos históricos, em especial para a diferenciação, em âmbito supranacional, da evolução do Direito no bojo dos sistemas de tradição common law e civil law e para a análise 
das repercussões do ativismo judicial em cada um desses sistemas. Já em âmbito nacional, o exame histórico deu lastro à compreensão dos motivos que conduziram à crise institucional que hoje se verifica, com a proeminência do Judiciário frente aos demais Poderes.

Da zetética analítica, por seu turno, buscaram-se referências de suas dimensões pura e aplicada, em especial nos âmbitos da filosofia do Direito, da teoria do Direito e da lógica do raciocínio jurídico. No campo da filosofia do Direito, o estudo repousou no conceito de positivismo e nos contornos do que se entende por moralismo jurídico. Da teoria do Direito, por seu turno, a análise abarcou o fenômeno do constitucionalismo e a ideia de neoconstitucionalismo (os quais também são marcados por contornos históricos da zetética empírica). Já a lógica do raciocínio jurídico foi usada para explicar os limites técnicos da função jurisdicional, abrangendo os contornos da hermenêutica para a aplicação da lei ao caso concreto pela Magistratura.

Eis, portanto, o diferencial da escolha metodológica. Optou-se pelo desenvolvimento da tese sob uma perspectiva puramente jurídica de ordem dogmática, com influxos tangenciais da zetética jurídica. Por essa razão, alguns conceitos comumente utilizados quando se discorre sobre ativismo judicial e função jurisdicional, tais como o da legitimidade democrática do Poder Judiciário, não foram utilizados no estudo desenvolvido. Em vez disso, enfoque foi dado à legitimidade constitucional desse Poder, visto que não houve pretensão de adentrar nos meandros da Ciência Política ou da Sociologia.

No que tange à pesquisa bibliográfica, o viés foi voltado à doutrina do Direito em perspectiva comparada, com a utilização de obras nacionais e estrangeiras que se fizeram necessárias ao estudo. Por se tratar de tese que demanda a análise de diferentes sistemas jurídicos e das repercussões da atuação jurisdicional ativista em cada um deles (common law e civil law), buscaram-se elementos bibliográficos nas Escolas de Direito que bem expressam os contornos de cada aparelho.

\section{I.3. Premissas teóricas}

Ao desenvolver uma tese, é preciso estabelecer um raciocínio lógico que conduza o objeto de estudo ao fim almejado pelo pesquisador. Para evitar que conceituações teóricas 
causem entraves ao bom desenvolvimento do trabalho, ou dúvidas quanto à sua completa compreensão, optou-se, já em nível introdutório, pelo estabelecimento das seguintes premissas teóricas e conceituais básicas:

\section{I.3.1. Separação de poderes e função jurisdicional}

Nas primeiras páginas desta Introdução, já se definiram os contornos do princípio da separação de poderes e da função jurisdicional. Porém, para fins de sistematização e de delimitação mais precisa desses conteúdos, opta-se por discorrer melhor sobre o tema no presente tópico.

De início, consigne-se que o termo "Poder" é grafado, ao longo do texto, com a letra inicial maiúscula sempre que vier acompanhado da nomenclatura dos blocos orgânicos que desempenham as funções do Estado: Legislativo, Executivo e Judiciário. A grafia será em inicial minúscula, porém, nas demais hipóteses de significações de tal vocábulo, inclusive na expressão "separação de poderes".

A distinção e a definição das funções do Estado ganharam destaque no período da Revolução Francesa, com a Assembleia Nacional de 1789, como uma das bases da regeneração política posterior à derrocada do Antigo Regime. Mas já desde Aristóteles é possível identificar o gérmen da teoria da separação de poderes, por meio de seus ensinamentos sobre as principais operações do Estado, quais sejam: a deliberação, o mando e a justiça. ${ }^{11}$

Na modernidade, John Locke advertiu sobre a utilidade da separação de poderes e identificou, no capítulo XII de seu "Segundo Tratado sobre o Governo Civil", a existência de três poderes que se convertem em dois: o Legislativo, o Executivo e o Federativo. Este último teria a incumbência de administrar a segurança e o interesse público externo, enquanto o Poder Executivo executaria as leis internas. Para Locke, ambos - Poder Executivo e Poder Federativo -, embora distintos entre si, "dificilmente devem ser separados

\footnotetext{
${ }^{11}$ Cf. ARISTÓTELES. Ética a Nicômacos. 3. ed. Brasília: Editora Universidade de Brasília, 2001, p. 93-127.
} 
e colocados ao mesmo tempo nas mãos de pessoas distintas", porque "submeter a força pública a comandos diferentes" acarretaria "desordem e ruína". ${ }^{12}$

Mas foi Montesquieu quem desenvolveu a verdadeira fórmula da moderna teoria da separação de poderes, com a preocupação de apartar o exercício das funções do Estado entre titulares diversos. Em seu "O Espírito das Leis”, Livro XI, Capítulo VI, consigna o seguinte:

\begin{abstract}
Quando, na mesma pessoa ou no mesmo corpo de magistratura, o poder legislativo está reunido ao poder executivo, não existe liberdade; porque se pode temer que o mesmo monarca ou o mesmo senado crie leis tirânicas para executá-las tiranicamente.

Tampouco existe liberdade se o poder de julgar não for separado doo poder legislativo e do executivo. Se estivesse unido ao poder legislativo, o poder sobre a vida e a liberdade dos cidadãos seria arbitrário, pois o juiz seria legislador. Se estivesse unido ao poder executivo, o juiz poderia ter a força de um opressor.

Tudo estaria perdido se o mesmo homem, ou o mesmo corpo dos principais, ou dos nobres, ou do povo exercesse os três poderes: o de fazer as leis, o de executar as resoluções públicas e o de julgar os crimes ou as querelas entre os particulares. ${ }^{13}$
\end{abstract}

Sendo certo, portanto, que a concepção de Montesquieu orienta a leitura e a compreensão do conteúdo do princípio da separação de poderes, há de se precisar o conteúdo material de cada uma das funções do Estado, para que sejam exercidas dentro de seus limites.

Ao presente trabalho importa definir os contornos específicos do Poder Judiciário. Porém, sendo certo que as definições podem partir não apenas do que o objeto é, mas também do que ele não é, comecemos consignando o que não é típico exercício da função jurisdicional.

Assim, em termos gerais, a criação de normas jurídicas abstratas que inovem originariamente na ordem jurídica e regulem uma pluralidade de casos, ou que tenham eco individual, não é função típica do Judiciário, mas sim do Poder Legislativo.

E, em que pese incumba tanto à função jurisdicional, quando à administrativa, a aplicação da lei, é oportuno transcrever a definição de Celso Antonio Bandeira de Mello, que estabelece os contornos que permitem a diferenciação de ambas:

Função administrativa é a função que o Estado, ou quem lhe faça as vezes, exerce na intimidade de uma estrutura e regime hierárquicos e que no sistema constitucional brasileiro se caracteriza pelo fato de ser desempenhada mediante

\footnotetext{
${ }^{12}$ LOCKE, John. Segundo tratado sobre o governo civil e outros escritos. Petrópolis: Vozes, 1994, p. 171-2.

${ }^{13}$ MONTESQUIEU. O espírito das leis. Trad. Cristina Murachco. São Paulo: Martins Fontes, 2000, p. 168.
} 
comportamentos infralegais ou, excepcionalmente, infraconstitucionais, submissos todos a controle de legalidade pelo Poder Judiciário. ${ }^{14}$

A função judiciária, por seu turno, é exercida por agentes públicos membros da Magistratura (não havendo a possibilidade de substituí-los por "quem lhe faça as vezes", como na função administrativa), que aplicam a lei ou, diretamente, a Constituição, para a solução de casos concretos, podendo, ainda, afastar a aplicação de leis inconstitucionais por meio de realização de controle de constitucionalidade concreto ou abstrato.

Não se deve centralizar a concepção de função jurisdicional à solução de litígios jurídicos, ou seja, de contendas processuais. Isso deixaria de fora atos como os de homologação de acordos e decisões sobre ações de jurisdição voluntária, tais como interdições, inventários e alterações de registro civil.

Por isso, parece muito adequada a definição de Carré de Malberg, para quem a tarefa jurisdicional consiste, seja em litígio ou fora dele, em reconhecer o Direito a ser aplicado no caso concreto, com base em prescrições normativas previamente estabelecidas. Portanto, julgar é reconhecer e declarar a lei aplicável. De forma geral, consiste em dizer o Direito; em pronunciá-lo. ${ }^{15}$

Sem prejuízo das funções típicas ora delineadas, cada Poder também realiza funções atípicas e está sujeito a um sistema limitador de freios e contrapesos. As competências materiais, portanto, não são estanques. Acerca desses tópicos se discorrerá no decorrer do trabalho.

\section{I.3.2. Classificação dos magistrados no rol de agentes públicos}

Costuma ser preocupação dos estudiosos do Direito Administrativo a classificação de determinadas categorias de objetos de estudo para fins de, mediante a sistematização, obter-se melhor compreensão didática. Dentre tais categorias se encontra o rol de agentes

\footnotetext{
${ }^{14}$ BANDEIRA DE MELLO, Celso Antonio. Curso de Direito Administrativo... op. cit., p. 36.

${ }^{15}$ Cf. MALBERG, R. Carré de. Teoría general del Estado. Trad. para o espanhol de José Lión Depetre. México: Fondo de Cultura Económica, 2001, p. 635.
} 
públicos, que abarcam agentes políticos, servidores públicos, militares e particulares em colaboração com o Estado.

O debate sobre o enquadramento dos membros da Magistratura no rol de agentes políticos, ou de servidores públicos estatutários, ainda permeia a doutrina administrativista. O posicionamento dominante é no sentido de que os agentes políticos são, tão somente, aqueles que ocupam cargos que compõem o arcabouço constitucional do Estado e o esquema fundamental do poder, englobando apenas o Presidente da República, os Governadores, os Prefeitos, os Ministros e os Secretários das diversas pastas, os Senadores, Deputados e Vereadores, de modo que neles não estariam incluídos os juízes. ${ }^{16}$

Em um conceito mais amplo, agentes políticos são classificados como componentes do Governo em seus primeiros escalões, investidos em cargos, funções, mandatos ou comissões, quer por nomeação, eleição, designação ou delegação para o exercício de atribuições constitucionalmente previstas, neles podendo ser incluídos tanto os Chefes do Poder Executivo e seus auxiliares diretos, quanto os membros do Poder Legislativo e, além deles, também os magistrados, os membros do Ministério Público e dos Tribunais de Contas, além dos representantes diplomáticos, que "atuam com plena liberdade funcional, desempenhando suas atribuições com prerrogativas e responsabilidades próprias, estabelecidas na Constituição e em leis especiais". ${ }^{17}$

Pois bem. Em que pesem as classificações doutrinárias administrativistas, não há razão, neste estudo, para se optar pela alocação dos magistrados em uma ou outra categoria. A premissa teórica acerca desse assunto se restringe ao seguinte: os juízes são servidores públicos em sentido lato (agentes públicos), integrantes do Poder Judiciário. Suas decisões, em maior ou menor grau, surtem reflexos sociais - mais restritos em casos que versam sobre questões individuais e adstritas às partes do processo, ou mais amplos conforme a dimensão e o alcance do comando jurisdicional (a exemplo das demandas que versam sobre direitos metaindividuais: difusos, coletivos e individuais homogêneos).

O processo em si, em verdade, não é apenas um instrumento técnico, mas a exteriorização do fenômeno jurídico, sofrendo inegáveis influências de fatores históricos,

\footnotetext{
${ }^{16}$ Cf. BANDEIRA DE MELlO, Celso Antonio. Curso de Direito Administrativo... op. cit., p. 245; DI PIETRO, Maria Sylvia Zanella. Direito Administrativo. 23. ed. São Paulo: Atlas, 2010, p. 512.

${ }^{17}$ MEIRELLES, Hely Lopes. Direito Administrativo Brasileiro... op. cit., p. 77.
} 
sociológicos e políticos, até mesmo como decorrência das premissas constitucionais que orientam a disciplina processual e a atuação de seus atores. ${ }^{18}$

Independentemente da amplitude da repercussão das decisões, não podem estas ser pautadas por razões de cunho ideológico dos magistrados, ou para fins de atendimento de reclamos políticos ou partidários. Por isso, ainda que ocupem altos escalões do Estado e devam atuar com liberdade funcional, sob um sistema de prerrogativas e sujeições próprias e especiais, os magistrados não devem agir como se políticos eleitos fossem, visto que suas garantias especiais do cargo lhes impõem atuação independente de pressões externas.

\section{I.3.3. Legitimidade constitucional do Poder Judiciário}

A questão da legitimidade do poder é mais atrelada à Ciência Política do que ao Direito propriamente dito. Considera-se legítimo o ato ou o agente que possua a necessária qualidade para tornar válida a sua atuação em face dos cidadãos. ${ }^{19}$

No âmbito estatal, as autoridades públicas estabelecem uma relação de domínio perante a sociedade, consistente no poder de fazer valer suas decisões em um ambiente em que o povo se vê suscetível a obedecer tais comandos gerais ou específicos.

A justificação material da relação de domínio reconduz ao conceito de legitimidade do poder político, que pode ser definida, nos dizeres de Carlos Blanco de Morais, como "o conjunto de vínculos, valores e princípios de ordem cultural, política e jurídica que justificam junto dos governados, o tipo de autoridade titulada e exercida pelos governantes". ${ }^{20}$

Ainda segundo o citado autor, a legitimidade pode assumir três formas principais: (i) legitimidade tradicional, fundamentada na aceitação sacralizada de pactos ou regras costumeiras presentes desde tempos imemoriais, como no caso da legitimidade paternal (pater famílias) ou da legitimidade dos monarcas hereditários; (ii) legitimidade carismática,

${ }^{18}$ Cf. CINTRA, Antonio Carlos de Araújo; GRINOVER, Ada Pellegrini; DINAMARCO, Cândido Rangel. Teoria geral do processo. 25. ed. São Paulo: Malheiros, 2009, p. 85.

${ }^{19}$ Cf. SILVA, De Plácido e. Vocabulário jurídico. Rio de Janeiro: Forense, 2008, p. 828.

${ }^{20}$ MORAIS, Carlos Blanco de. O sistema político no contexto da erosão da democracia representativa. Coimbra: Almedina, 2017, p. 46. 
decorrente de razões emocionais ou afetivas que rodeiam determinados líderes políticos, elevados à posição de heróis, salvadores ou profetas, ainda que demonstrem viés autoritário ou ideologicamente extremado; (iii) legitimidade legal-racional, fundada na obediência de governantes e governados à legalidade em sentido amplo, estabelecendo-se, assim, uma relação de domínio de índole formal. ${ }^{21}$

Nessa última espécie se situa a legitimidade democrática, assentada sobre a ficção do contrato social, do qual decorre o fundamento da autoridade dos governantes, ou seja, do consentimento expresso por uma vontade livre, periódica e explícita dos governados. ${ }^{22}$ Tal noção alinha-se, a princípio, à ideia de eletividade dos governos, em especial quando se fala em expressão da vontade dos cidadãos, livremente manifestada de tempos em tempos.

Porém, a Constituição Federal em si é fruto da identidade do poder político do Estado, estatuindo as relações da sociedade com esse poder. Trata-se, portanto, de norma superior de referência da ordem jurídica, possuindo legitimidade por excelência. ${ }^{23}$ Daí porque, ao outorgar imperatividade às decisões judiciais e autoridade aos membros do Poder Judiciário, estes, mesmo não sendo eleitos diretamente pelo voto popular, presumem-se legitimados para exercer seus cargos e para impor o cumprimento de suas decisões à sociedade. $^{24}$

\section{I.3.4. Discricionariedade}

O estudo da discricionariedade tem sido melhor desenvolvido pelo Direito Administrativo do que nos demais ramos da Ciência Jurídica. Segundo Celso Antonio Bandeira de Mello, discricionariedade administrativa pode ser definida como:

\footnotetext{
${ }^{21}$ Idem, p. 48-9.

${ }^{22}$ Idem, p. 51.

${ }^{23}$ Cf. WEBER, Max. Economia y sociedade. México: Fondo de Cultura Económica, 1964, p. 77 e ss.

${ }^{24}$ Acerca da legitimidade dos Tribunais Constitucionais, ensina Jorge Miranda: "Em estritos termos jurídicos, a legitimidade do Tribunal Constitucional não é maior, nem menor do que a dos órgãos políticos: advém da Constituição. E, se esta Constituição deriva de um poder constituinte democrático, então ela há-de ser, natural e forçosamente, uma legitimidade democrática." E prossegue, mais adiante: "É, justamente, por os juízes constitucionais serem escolhidos por órgãos democraticamente legitimados - em coerência, por todos quantos a Constituição preveja, correspondentes ao sistema de governo consagrado - que eles podem invalidar actos com a força de lei. É por eles, embora por via indirecta, provirem da mesma origem dos titulares de órgãos políticos que por estes conseguem fazer-se acatar" (MIRANDA, Jorge. Manual de Direito Constitucional. Coimbra: Coimbra Editora, 2001, t. 6, p. 117 e 121).
} 
(...) a margem de liberdade que remanesça ao administrador para eleger, segundo critérios consistentes de razoabilidade, um, dentre pelo menos dois comportamentos cabíveis, perante cada caso concreto, a fim de cumprir o dever de adotar a solução mais adequada à satisfação da finalidade legal, quando, por força da fluidez das expressões da lei ou da liberdade conferida no mandamento, dela não se possa extrair objetivamente, uma solução unívoca para a situação vertente. $^{25}$

As nuances do referido conceito podem ser incorporadas também ao exercício de discricionariedade em outras esferas do Estado. Por isso, quando, no decorrer do trabalho, se faz menção a tal termo, seu significado sempre exprime o agir de acordo com a moldura imposta pela norma específica ou pelo ordenamento jurídico como um todo.

Difere, assim, a discricionaridade da arbitrariedade, sendo certo que a primeira é legítimo exercício de competência decisória nos estritos limites da legalidade, e a segunda consiste em desvio de conduta do operador do Direito, quando este age de acordo com inclinações pessoais ou autoritárias, em detrimento do interesse público.

O agir discricionário, portanto, nunca é arbitrário. Se houver arbitrariedade, não há correto exercício de competência discricionária.

\section{I.3.5. Lei e legalidade}

O vocábulo lei, em sentido formal e estrito, refere-se, segundo conceituação de José Afonso da Silva, "ao ato legislativo emanado dos órgãos de representação popular e elaborado em conformidade com o processo legislativo previsto na Constituição (arts. 59 a $69) " .26$

Nesse viés, a legalidade em sentido estrito, enquanto princípio constitucional, é a qualidade do que é legal, ou seja, do que está em conformidade a lei em sentido formal.

Porém, para fins do presente estudo, a menção aos termos lei e legalidade se dá, no mais das vezes, em seu sentido lato. Desse modo, lei é considerada sinônimo de norma ou de ato normativo, a abarcar o conjunto de regras e princípios que compõem o ordenamento jurídico. E legalidade, na mesma esteira, passa a ser tomada em seu sentido amplo,

${ }^{25}$ BANDEIRA DE MELLO, Celso Antonio. Discricionariedade e Controle Jurisdicional. 2. ed. São Paulo: Malheiros, 2003, p. 48.

${ }^{26}$ SILVA, José Afonso da. Curso de Direito Constitucional Positivo... ob. cit., p. 420-1. 
“entendida esta como a qualidade do que está conforme ou compatível com a ordem jurídica, e não apenas com a lei em sentido estrito", ${ }^{27}$

No decorrer do trabalho, quando se pretende fazer referência à lei em sentido formal e à legalidade em sentido estrito, deixa-se clara e expressa a intenção, a exemplo da consignação de termos como "lei ordinária", "lei complementar" e "lei delegada", ou à menção do diploma normativo específico, com a nomenclatura que o individualiza (ex.: Lei n. 6.683 , de 28 de agosto de 1979 - Lei da Anistia).

\section{I.3.6. Sistemas jurídicos de tradição "common law" $e$ "civil law"}

A tradição civilística de Direito (civil law) é a mais antiga e ampla no mundo. Suas origens remontam a 450 a.C., a partir da "Lei das Doze Tábuas", que foi o primeiro e rudimentar sistema escrito de solução de conflitos na Roma Antiga. Posteriormente, o Imperador Justiniano de Constantinopla determinou a positivação do Corpus Juris Civile, com a codificação do Direito Romano para disciplinar temas relacionados, dentre outros, à família, sucessões, propriedade e contratos. Com a queda do Império Romano, tal legislação caiu em desuso no curso da Idade Média, voltando a ser estudada no período do Renascimento europeu, com a gradativa sistematização do Direito Privado, do Direito Público, do Direito Processual e do Direito Penal. Assim, o sistema civil law se espalhou pela Europa e pelas colônias da América do Sul, África, Oriente Médio e Ásia. ${ }^{28}$

A tradição do sistema common law, por seu turno, emergiu da conquista da Inglaterra pelos normandos, em 1066 d.C. Naquela época, William, “o Conquistador”, com o intuito de fixar a lei normanda no país estrangeiro, delegou a um corpo de juízes leais a competência para resolverem os conflitos locais, mediante a produção de soluções normativas. Também foi incorporada àquele sistema a figura do júri, composto por jurados que representavam os interesses da localidade, como estratégia para acalmar os ânimos da população e fazê-la se sentir acolhida pelos novos ocupantes do poder. Porém, por se

27 CAMMAROSANO, Márcio. O princípio constitucional da moralidade e o exercício da função administrativa. Belo Horizonte: Fórum, 2006, p. 102.

${ }^{28}$ Cf. MERRYMAN, John Henry. The civil law tradition: an introduction to the legal systems of Western Europe and Latin America. 2. ed. Standford: Standford University Press, 1985, p. 2-10. 
tratarem, tais jurados, no mais das vezes, de pessoas simples e não-letrados, os procedimentos passaram a ser orais. Daí porque se diz que o desenvolvimento do sistema common law foi um "acidente histórico". A ausência da escrita fez com que a tradição do direito comum assumisse contornos diversos da legislação positivada, espraiando-se essa práxis, posteriormente, para a América do Norte e para as colônias inglesas, incluindo Estados Unidos, Austrália, Canadá, África do Sul, Nova Zelândia, Índia, Zimbábue, Gana, Zâmbia, Botsuana, Nigéria, Somália, Tanzânia, Gâmbia, Serra Leoa, Malawi e muitas ilhas caribenhas. $^{29}$

Em linhas gerais, as fontes do Direito no sistema civil law derivam da legislação formal, emanada do Parlamento (Poder Legislativo), com obediência à hierarquia das leis, consoante o sistema piramidal esquematizado por Hans Kelsen, no qual se situa, no topo, a Constituição Federal. Os tratados e convenções internacionais também são fontes do Direito, quando incorporados ao ordenamento jurídico pátrio por meio dos procedimentos constitucionalmente previstos para tanto - respeitada a soberania nacional.

Questão mais polêmica surge quando se passam a analisar os costumes. Prescreve a LINDB, em seu art. 4", que: "Quando a lei for omissa, o juiz decidirá o caso de acordo com a analogia, os costumes e os princípios gerais do direito". Para que sejam aplicados como fonte do Direito, em especial para a colmatação de lacunas aparentes da lei, os costumes devem ser considerados elementos propriamente jurídicos, traduzindo, nos dizeres de André Franco Montoro, "a longa, inveterada, diuturna, consuetudo dos romanos, relativa a determinada situação de fato e observada com a convicção de corresponder a uma necessidade jurídica". ${ }^{30}$

No sistema de direito legislado, os costumes só podem ser aplicados se forem, portanto, verdadeiras normas jurídicas, não se confundindo com meras práticas ou usos coletivos de natureza social, moral ou religiosa que decorram de simples tradição ou conveniência. Sua relevância deriva, pois, de sua obrigatoriedade jurídica, e seu uso é mais comum em áreas como o Direito Comercial, a teor da menção à aplicação de "usos e costumes", consoante já há muito previam os Atos de Comércio (art. $2^{\circ}$ do antigo Regulamento 737/1850), bem como o Direito Internacional, com sua inerente tradição de

\footnotetext{
${ }^{29}$ Cf. GLENN, H. Patrick. Legal traditions of the world. 2. ed. Oxford: Oxford University Press, 2004, p. 2239.

${ }^{30}$ MONTORO, André Franco. Introdução à Ciência do Direito. 26. ed. São Paulo: Revista dos Tribunais, 2005 , p. 405.
} 
convencionalidade. Em outras áreas, como o Direito Penal moderno, não se admite a utilização dos costumes, dado o princípio que veda a existência de crime sem lei (em sentido formal) anterior que o defina, nem pena sem prévia cominação legal. ${ }^{31}$

E ponto ainda mais polêmico diz respeito à utilização da jurisprudência enquanto fonte do Direito nos sistemas de tradição civil law, podendo ser considerada "costume jurisprudencial". Nos ordenamentos de origem common law, o Direito se constrói historicamente a partir de casos concretos, mediante a utilização de princípios gerais para a solução das demandas práticas. Nesse contexto, o papel dos juízes é de verdadeira produção normativa com força de precedentes em meio ao sistema denominado stare decisis, que visa assegurar certeza, equidade e consistência ao Direito construído. Daí a relevância da jurisprudência em tais ordenamentos. ${ }^{32}$

Além disso, desde os primórdios do sistema common law - conforme já dito acerca da invasão da Inglaterra pelos normandos -, os juízes ocupam posição de alto relevo e respeitabilidade perante a sociedade e o Poder Público. Desde William, “o Conquistador”, que delegou a um corpo de juízes leais a competência para a solução dos conflitos nas terras inglesas à época recém-conquistadas, até a atualidade, os magistrados anglo-saxões não são considerados meros funcionários públicos, mas são escolhidos dentre os melhores advogados do país para assumir a honrosa função judicante, à qual se confere grande prestígio. $^{33}$

Já no Direito Continental de tradição romanística (civil law), tendeu-se a pairar sobre a figura do juiz uma certa desconfiança social que se tornou bem nítida na época da Revolução Francesa, quando os magistrados eram vistos como homens do Antigo Regime. Por isso, no contexto pós-revolucionário, cuidou-se de limitar-lhes o poder, para que se restringissem a aplicar os comandos da lei codificada. ${ }^{34}$

Isso não significa que a jurisprudência não possua relevância no direito codificado. O respeito à lei e a proibição da decisão contra legem são regras estruturantes desse sistema, mas o entendimento jurisprudencial - em especial o pacificado - permite a formação de

\footnotetext{
${ }^{31}$ Idem, p. 406-7.

32 Cf. O’CONNOR, Vivienne. Common law and civil law traditions. INPROL - International Network to Promote the Rule of Law, mar./2012, p. 13-4.

${ }^{33}$ Cf. FERRAZ JR., Tercio Sampaio. Introdução ao estudo do Direito. 4. ed. São Paulo: Atlas, 2007, p. 244.

${ }^{34}$ Idem, p. 244-5.
} 
interpretações uniformes e constantes, que não inovam a lei, mas lhe dão um sentido geral de orientação.

Mesmo em um contexto de existência de súmulas vinculantes e de uniformização da jurisprudência dos Tribunais ${ }^{35}$, estas incide apenas em um segundo momento. Ou seja: nos sistemas de tradição civil law, a lei precede a decisão judicial, e esta é embasada na aplicação da norma ao caso concreto, após o exercício interpretativo. Por esse contraponto, evidencia-se que "lei e jurisprudência têm natureza diversa, prendendo-se a diferentes instituições, e se reportando a distintos eventos cronológicos". ${ }^{36}$

Quanto a este tópico, esclareça-se, por fim, que no trabalho se utilizam as expressões common law e civil law precedidas do artigo masculino "o" (e não no feminino, como muitos empregam) porque a referência é feita aos sistemas jurídicos (substantivos masculinos) e não à lei comum ou civil.

\section{I.3.7. Constitucionalismo e neoconstitucionalismo}

Na superação do feudalismo para o capitalismo, a industrialização demandou a plenitude da liberdade de ação e de contratação. Como reflexo dessa necessidade, a sociedade civil passou a exigir uma Constituição que garantisse a liberdade individual contra o absolutismo. Para impor o novo regime liberal, não bastava positivar - em forma escrita a pretérita Constituição costumeira. Tornou-se necessário introduzir ao texto dois mecanismos capazes de coibir os abusos do poder político, quais sejam: a separação de poderes e a declaração de direitos. ${ }^{37}$

Os adeptos do neoconstitucionalismo costumam identificar no constitucionalismo dois modelos distintos de Constituições escritas, a saber: a americana, de 1787, e a francesa,

\footnotetext{
${ }^{35}$ Cf. CPC-15, “Art. 926. Os tribunais devem uniformizar sua jurisprudência e mantê-la estável, íntegra e coerente. $\S 1^{\circ} \mathrm{Na}$ forma estabelecida e segundo os pressupostos fixados no regimento interno, os tribunais editarão enunciados de súmula correspondentes a sua jurisprudência dominante. $\S 2^{\circ}$ Ao editar enunciados de súmula, os tribunais devem ater-se às circunstâncias fáticas dos precedentes que motivaram sua criação."

36 MANCUSO, Rodolfo de Camargo. Sistema brasileiro de precedentes. 2. ed. São Paulo: Revista dos Tribunais, 2016, p. 79.

${ }^{37}$ Cf. BARROS, Sérgio Resende de. Contribuição dialética para o constitucionalismo. Campinas: Millennium, 2008, p. 251-2.
} 
de 1791. Afirmam que o modelo francês possuía dimensão eminentemente política, destacando-se a supremacia do Parlamento para a codificação das leis infraconstitucionais, e que o sistema americano abriu margem, por meio do princípio da supremacia da Constituição, à possibilidade de a Suprema Corte exercer o controle de constitucionalidade das normas. ${ }^{38}$

Ao discorrer sobre o tema, Luís Roberto Barroso destaca um possível novo direito constitucional, marcado pelo reconhecimento da força normativa da Constituição, pela expansão da jurisdição constitucional e pelo desenvolvimento de uma nova dogmática de interpretação, com um viés mais proativo das cortes constitucionais para a concretização dos direitos fundamentais, com a discussão, ainda, sobre a fronteira entre direito e política, ou seja, entre o que é interpretação constitucional e o que deve ser reservado ao espaço de conformação legislativa. ${ }^{39}$ Nas palavras do autor:

\begin{abstract}
É essa visão não formalista e não (tão) positivista do Direito e da vida, aliada à centralidade da Constituição, que tem sido apelidada no Brasil de neoconstitucionalismo. $\mathrm{O}$ termo tem, em primeiro lugar, uma dimensão descritiva: ele identifica um conjunto importante de mudanças ocorridas no constitucionalismo contemporâneo, identificadas acima, que incluem: a) a elaboração de Constituições analíticas, com dispositivos voltados à proteção dos direitos fundamentais de diversas gerações; b) a expansão da jurisdição constitucional em todo o mundo, com a criação de tribunais constitucionais ou cortes supremas destinadas a fazerem valer a Constituição; e c) a ascensão institucional do Poder Judiciário e o aumento da discricionaridade judicial, em razão da complexidade da vida moderna e de uma percepção da interpretação constitucional. ${ }^{40}$
\end{abstract}

Trata-se de movimento que tende a analisar a evolução do constitucionalismo sob influxos axiológicos que superam a tradicional dicotomia entre Direito e Moral, ou entre Direito e Justiça, de modo que, para seus adeptos, a interpretação constitucional deve ter o escopo de realização da justiça social e de justiça universal.

Isso decorre de reclamos que surgiram especialmente após a Segunda Guerra Mundial, período em passaram a ascender correntes refratárias ao positivismo exacerbado, em especial devido às atrocidades praticadas por Estados legalistas de cunho autoritário - a teor do fascismo e do nazismo. Daí porque o neoconstitucionalismo passa a ser defendido como toda intepretação constitucional que utilize elementos não positivados de maneira

\footnotetext{
38 BARROSO, Luís Roberto. O constitucionalismo democrático ou neoconstitucionalismo como ideologia vitoriosa do século XX. Revista Publicum, Rio de Janeiro, v. 4. Edição Comemorativa, 2018, p. 18.

${ }^{39}$ Idem, p. 24.

${ }^{40}$ Idem, p. 25.
} 
expressa ou implícita, mas passíveis de serem inferidos historicamente. Sua legitimação decorreria, assim, de seu próprio conteúdo, idealizado com vistas ao reconhecimento dos direitos inerentes a qualquer pessoa humana, a partir de postulados morais e de justiça. ${ }^{41}$

Críticas à visão neoconstitucionalista são feitas no decorrer do trabalho. Por ora, basta deixar consignada a conceituação dos termos ora analisados.

Quando ao constitucionalismo em si, Sérgio Resende de Barros "aconselha chamar constitucionalização o ato (a produção da Constituição) e Constituição, o efeito (o produto constituído), dos quais o constitucionalismo é o processo prático-teórico". ${ }^{42}$ E prossegue afirmando que o "constitucionalismo é o processo prático-teórico de elaboração, interpretação e aplicação da Constituição"43.

Das lições do citado autor, merece, ainda, destaque o seguinte excerto:

(...) Historicamente, superado o primeiro momento, vencido o Estado absoluto, a Constituição exauriu sua primitiva função ideológica revolucionária: a defesa da liberdade individual contra a arbitrariedade política. Gradualmente se reduziu à sua práxis cotidiana. A Constituição perdeu o vetor ideológico exclusivo com que nasceu. O constitucionalismo deixou de ser uma ideologia para ser o movimento prático-teórico do direito constitucional: o processo da Constituição. Os efeitos constituídos são causas constituintes de outras constituições. Toda a constituição da sociedade humana é um processo. Como especificidade do direito constitucional, na sua dinâmica histórica, o processo da Constituição é o próprio constitucionalismo, que nessa condição deve ser analisado. ${ }^{44}$

Daí concluir-se que o constitucionalismo teve uma origem histórica específica, mas se protrai no tempo através da renovação dos processos constituintes. Abandonado o viés puramente ideológico inicial, o constitucionalismo continua a existir enquanto fenômeno prático-teórico do Direito Constitucional.

Desse modo, parece não haver necessidade de se empregar o neologismo neoconstitucionalismo. Enquanto produto histórico de renovação constante, o que sempre se verifica é o constitucionalismo em si, ao qual são inerentes as transformações advindas da evolução social.

${ }^{41}$ Cf. QUINTILIANO, Leonardo David. Direitos sociais e vinculação do legislador: as reformas previdenciárias e seus limites constitucionais no Estado Social e de Direito. Rio de Janeiro: Lumen Juris, 2019, p. 42-3.

${ }^{42}$ BARROS, Sérgio Resende de. Contribuição dialética para o constitucionalismo... op. cit., p. 252.

${ }^{43}$ Idem, p. 254

${ }^{44}$ Idem, p. 240. 


\section{I.3.8. Princípios jurídicos e princípios constitucionais}

As normas, em si, não são textos jurídicos, mas consistem no sentido que advém da intepretação desses textos, de modo que aquelas são o resultado destes. ${ }^{45}$ São o gênero do qual derivam as espécies regras e princípios.

Segundo definição de Humberto Ávila, as regras são normas imediatamente descritivas, primariamente retrospectivas e com pretensão de coercibilidade e abrangência. Podem ser comportamentais ou constitutivas: as normas comportamentais preveem comportamentos conforme critérios de obrigatoriedade, permissão ou proibição. As constitutivas, por seu turno, atribuem efeitos jurídicos a certos atos, situações ou fatos (ex.: dispositivos normativos relativos à distribuição, reserva e delimitação substancial de competência). ${ }^{46}$

Os princípios são normas que estabelecem uma orientação prática a se seguir para o atingimento de um fim, de modo que são imediatamente finalísticos. São diretrizes de conduta. Inegavelmente, se relacionam com o campo dos valores, mas com estes não se confundem, visto que, ao contrário destes, os princípios residem no campo deontológico e estabelecem a obrigatoriedade de adoção de determinadas condutas para a promoção gradual de um estado de coisas. Os valores, por sua vez, reservados ao campo axiológico, se restringem a meramente atribuir uma qualidade positiva a dado comportamento. ${ }^{47}$

Pois bem. Adentrando no campo constitucional, adota-se, para fins do estudo desenvolvido no presente trabalho, a concepção de que princípios constitucionais são tanto aqueles que a própria Constituição assim define, qualquer que seja seu conteúdo (ex.: princípios da Administração Pública, expressos no caput do art. 37, da CRFB-88) ${ }^{48}$, quanto os que atendem a critérios sistematizados pela doutrina, ou seja, normas que se revistam de conteúdo principiológico, ainda que não tenham sido expressamente referidas como tal no

\footnotetext{
${ }^{45}$ Cf. ÁVILA, Humberto. Teoria dos princípios jurídicos: da definição à aplicação dos princípios jurídicos. 14. ed. São Paulo: Malheiros, 2013, p. 33.

${ }^{46}$ Idem, p. 87-8.

${ }^{47}$ Idem, p. 87.

${ }^{48}$ CRFB-88, “Art. 37. A administração pública direta e indireta de qualquer dos Poderes da União, dos Estados, do Distrito Federal e dos Municípios obedecerá aos princípios de legalidade, impessoalidade, moralidade, publicidade e eficiência e, também, ao seguinte: (...)".
} 
texto constitucional ${ }^{49}$ (ex.: as normas contidas no caput e nos incisos do art. $5^{\circ}$ da CRFB-88, apesar de terem sido designadas "direitos e garantias fundamentais", podem ser consideradas verdadeiros princípios constitucionais).

${ }^{49}$ A distinção qualitativa entre regras e princípios é bem delineada por José Joaquim Gomes Canotilho, segundo o qual: “(...) a) os princípios são normas jurídicas impositivas de uma otimização, compatíveis com vários graus de concretização, consoante os condicionalismos fácticos e jurídicos; as regras são normas que prescrevem imperativamente uma exigência (impõem, permitem ou proíbem) que é ou não é cumprida; b) a convivência dos princípios é conflitual; a convivência das regras é antinômica; c) os princípios coexistem, as regras antinômicas excluem-se; d) os princípios permitem o balanceamento de valores e interesses (não obedecem, como as regras, a lógica do tudo ou nada), consoante o seu peso e a ponderação de outros princípios eventualmente conflitantes; as regras não deixam espaço para qualquer outra solução, pois se uma regra vale deve cumprir-se na exata medida das suas prescrições, nem mais nem menos; e) os princípios podem ser objetos de ponderação, de harmonização, pois eles contêm apenas exigências que, em primeira linha (prima facie) devem ser realizados; as regras contêm fixações normativas (definitivas), sendo insustentável a validade simultânea de regras contraditórias; f) os princípios suscitam problemas de validade e peso (importância, ponderação, valia); as regras colocam apenas questões de validade (se elas não são corretas devem ser alteradas)" (CANOTILHO, José Joaquim Gomes. Direito constitucional e teoria da constituição. 7. ed. Coimbra: Almedina, 2003, p. 1161-2). 


\section{TERCEIRA SÍNTESE CONCLUSIVA}

A análise de todo o comportamento judicial aqui delineado, inclusive com relação às limitações impostas pela Constituição à função jurisdicional, pressupõe a existência de um sistema embasado nas premissas do Estado de Direito. Em Estados legalistas, ou seja, de mera legalidade formal, sem conteúdo axiológico justo, há a deterioração do conceito de direitos fundamentais, de modo que a verificação de limites para a contenção do poder muito reduzida, ou totalmente inexistente.

Ou seja, em um Estado que, em suas relações com o povo e para a garantia dos direitos individuais, submete-se a si próprio a um regime de Direito, composto por normas que garantem os cidadãos e prescrevem os meios que o Poder Público deve realizar para a concretização dos fins do governo - valendo a lei, em ambas as hipóteses, como instrumento limitador do arbítrio estatal.

Há, portanto, uma centralidade em torno dos cidadãos.

Eis, então, os elementos caracterizadores do de Estado de Direito: segurança jurídica, separação de poderes, limitação do poder por um sistema de freios e contrapesos, garantia dos direitos fundamentais da pessoa humana e regime democrático.

A limitação do poder, nesse contexto, é matéria que decorre dos postulados do Estado de Direito.

Não menos importante é a existência de um Poder Judiciário forte, independente e autônomo. Em verdade, a autonomia e a independência dos magistrados garantem aos cidadãos que suas liberdades fundamentais não serão limitadas a não ser nas hipóteses e na forma previstas em lei, sempre mediante justa atuação das autoridades judiciais.

Assim, os limites já expostos, em especial a segurança jurídica, os direitos e garantias fundamentais, a separação de poderes, o sistema de freios e contrapesos, o regime democrático e a independência do Poder Judiciário, são os nortes de verificação dos parâmetros da atividade jurisdicional.

O trabalho estabelece, então, hipóteses práticas que delineiam os contornos desses limites. 
Assim, em caso de omissões normativas inconstitucionais, decorrentes da inatividade do Poder Legislativo, essa inércia em si assume status de inconstitucionalidade. Para dar efetividade ao sistema, a CRFB-88 prevê instrumentos para o controle judicial das omissões normativas inconstitucionais, destacando-se: (i) o mandado de injunção, que tutela incidentalmente e in concreto os direitos subjetivos violados por ausência de norma regulamentadora que lhes dê eficácia; ${ }^{294}$ (ii) a ação de inconstitucionalidade por omissão, para o controle abstrato das omissões normativas inconstitucionais. A atuação jurisdicional, em ambos esses casos, não pode ser criativa no sentido de inovação originária na ordem jurídica, mas deve obedecer às balizas das normas constitucionais e legais postas que regulam esses instrumentos.

No mais, quando o Poder Judiciário intervém ativamente na esfera de competência dos demais poderes, sua atuação acaba por catalisar debates e ações que são próprios do sistema político, potencializando o cenário de deficiências sistêmicas preexistente.

Portanto, em especial relativamente a hipóteses que versam sobre políticas públicas, não pode o Judiciário fazer as vezes das instâncias políticas próprias para formulá-las, sob pena de, a depender da situação, colocar em risco até mesmo sua imparcialidade. Deve agir apenas para fins de controle de legalidade e de constitucionalidade das medidas tomadas pelo Legislativo e pelo Executivo, atuando de maneira positiva nos casos de omissões inconstitucionais, por meio dos já mencionados instrumentos: MI e ADO.

Até porque, com o intuito de intervir em políticas públicas, o Judiciário não raras vezes adentra em searas sobre as quais não possui conhecimento e domínio adequado, visto que não fazem parte de suas atribuições típicas, estabelecendo juízos a partir de premissas erradas, com consequências desastrosas.

Quanto à discricionariedade administrativa, pode o Judiciário controlá-la à luz da teoria do desvio de poder, mas não lhe cabe fazer as vezes do administrador e se imiscuir no campo decisório (de mérito), reanalisando a conveniência e a oportunidade da medida tomada. O controle legítimo é, pois, o de legalidade.

294 CRFB-88, “Art. 5, LXXI - conceder-se-á mandado de injunção sempre que a falta de norma regulamentadora torne inviável o exercício dos direitos e liberdades constitucionais e das prerrogativas inerentes à nacionalidade, à soberania e à cidadania”. 
Quanto aos atos eminentemente políticos, ou seja, aqueles restritos à esfera política, não há possibilidade de controle jurisdicional, visto que são afetos a matérias estruturantes do Estado e objeto de eleição pelo próprio constituinte. Tratam-se de reclamos que, a princípio, não podem sequer ser judicializáveis.

No que tange aos atos de chefia de Estado, sobre eles pode haver controle judicial mínimo, em casos de evidentes arbitrariedades. Exemplificativamente, em relação a conceitos vagos, como de "grave comprometimento da ordem pública", ou "comoção grave de repercussão nacional", pode o Judiciário declarar inconstitucional a atuação do Chefe de Estado que aja de maneira abusiva ou totalmente dissonante da razoabilidade. Seria o caso de controle em face de casos onde se pudesse verificar grande temeridade na atuação do Presidente da República.

Os atos interna corporis, por sua vez, podem ser controlados pelo Poder Judiciário no que tange à legalidade procedimental e, excepcionalmente, quanto ao mérito, para controle de arbitrariedades e teratologia.

Por fim, não se deve esquecer que, quando o Poder Judiciário ultrapassa tais limites, está sujeito a reações sistêmicas ou populares (backlashes). Exemplo disso são as manifestações populares pejorativas frente à postura de juízes e Ministros, ou as proposições legislativas que tentam criminalizar a atividade interpretativa realizada pelo Judiciário, sempre que supostamente seja inconstitucional - valoração que, se realizada pelas esferas políticas de governo, por certo pode sofrer os influxos de tendências ideológicas autoritárias.

Mas não se pode esquecer que o ativismo judicial é, por si, uma reação (por vezes necessária) à ineficiência dos demais poderes.

Ademais, o Judiciário, por sua natureza, é inerte, agindo apenas quando provocado.

Não fosse o fenômeno da judicialização crescente, decorrente das necessidades da população que não tem tido seus reclamos atendidos e bem disciplinados nas demais esferas de governo, não haveria qualquer postura ativista na seara judicial.

Assim, os parâmetros de limitação ora verificados devem servir de norte para a atuação do Poder Judiciário, mas só serão plenamente atendidos se partir das outras esferas de poder o comportamento ativo - também limitado constitucionalmente - que lhes é exigido. 


\section{CONSIDERAÇÕES FINAIS}

À guisa de encerramento, passemos às considerações finais do presente trabalho, elaboradas a partir de tudo quanto foi exposto, em especial das conclusões sintéticas desenvolvidas ao caso de cada uma das três partes do trabalho:

1. A lógica da separação de poderes demanda que o Executivo, o Legislativo e o Judiciário sejam independências e harmônicos entre si, sob pena de, sobressaindo um poder em relação ao outro, imporem-se riscos à manutenção da ordem constitucional.

2. Durante o período da Ditadura Militar pós-1964, o Brasil vivenciou a proeminência do Poder Executivo sobre os demais, com o desequilíbrio crítico da bala institucional do Estado. Ao cabo desse regime, a opção pela anistia política aos crimes cometidos durante aquele governo autoritário acabou por arraigar um sentimento de impunidade no seio social e de descrença nas instituições de poder - apesar de tal opção, à época, ter sido necessária para pavimentar os caminhos da redemocratização.

3. Os períodos que se seguiram, já sob a égide da redemocratização, também foram permeados por instabilidade política, inclusive em decorrência da ascensão de escândalos de corrupção e do impeachment de dois Presidentes da República que haviam sido eleitos democraticamente.

4. A CRFB-88, por seu turno, augurou uma ordem pluralista, com a positivação de grande gama de direitos e garantias, seguindo a tendência da constitucionalização abrangente que é comum após períodos totalitários e ditatoriais.

5. A concretude dos preceitos constitucionais, porém, demanda a atuação positiva dos poderes do Estado, mormente as instâncias decisórias políticas por excelência, quais seja, o Executivo e o Legislativo. 
6. Os direitos individuais prestacionais assumem status potencial de pretensões jurídicas. Por isso, diante da ineficiência ou na inação dos poderes políticos, podem os cidadãos se socorrer do Poder Judiciário em busca da efetivação de tais direitos.

7. Todavia, fenômenos como a espetacularização de julgamentos envolvendo casos de imenso interesse social, além da própria divulgação das sessões de julgamento em espaço televisivo (a exemplo da TV Justiça, que foi criada para essa finalidade), acabam por destacar não apenas informações técnicas de cunho jurídico, mas também a assuntos relacionados à individualidade dos julgadores.

8. Nesse contexto, a ideia de magistrados temidos e de alta respeitabilidade passou a ser substituída por uma proximidade maior entre a população e os juízes. A população em geral passa a conhecer Ministros do STF pelo nome, sabe suas feições físicas, seus gostos pessoais e, não raro, os critica com veemência, inclusive com ataques ofensivos e extremamente pejorativos.

9. Nota-se então, a ingerência de pressões populares e políticas sobre a atividade jurisdicional, desvirtuando-se as regras de conduta que devem pautar a atuação dos magistrados.

10. Assim, o ponto de partida do estudo dos limites da atividade jurisdicional deve ser a concepção de que os magistrados, no exercício da atividade jurisdicional, não são indivíduos, mas representam a personificação do próprio Poder Judiciário, motivo pelo qual possuem autoridade de poder do Estado.

11. Daí porque os limites constitucionais não são meros condicionantes de sua atividade, mas meios imprescindíveis ao bom funcionamento institucional e, como tal, garantidores, da autoridade (e não arbitrariedade) do Poder Judiciário e da respeitabilidade de suas decisões. 
12. A atividade jurisdicional por excelência é a interpretação do Direito, para fins de aplicálo com força de definitividade. Há, portanto, fixação do sentido das normas, com a determinação de seu conteúdo e alcance.

13. Tal exercício interpretativo não se restringe às hipóteses em que as normas são dúbias ou imprecisas. E verdade, vau além, traduzindo-se em imperativo necessário a todo ato de aplicação da lei, em atividade que não é meramente declaratória, mas constitutiva.

14. O juiz não é um ser alheio à sociedade e ao período histórico em que está inserido. Por isso, deve levar em consideração o Direito enquanto sistema, não agindo como um autômato, mas como um intérprete criativo.

15. Tal criatividade, porém, possui limites, não podendo significar inovação originária na ordem jurídica - papel este atribuído apenas ao legislador.

16. O sistema brasileiro, de tradição romanística (civil law), pode sofrer eventuais influxos do common law, mas com ele não se confunde. Por isso, princípios como o stare decisis não estão adaptados à ordem normativa pátria.

17. É predicado do sistema buscar, tanto quanto possível, a segurança jurídica. Para tanto, regras de sistematização da interpretação acabam por ser incorporadas à atividade jurisdicional, tal como a conveniência de se obedecer a precedentes da jurisprudência e às súmulas. Note-se: é conveniente que isso ocorra, mas não há obrigatoriedade.

18. São obrigatórias, porém, as súmulas vinculantes, mas estas não podem inovar originariamente na ordem jurídica. O que vincula é o norte de interpretação que imprimem aos textos normativos já vigentes.

19. Quando as súmulas vinculantes criam direito que não existia previamente, estabelecendo regras fundadas exclusivamente em princípios abertos, então seu conteúdo é inconstitucional. 
20. Outro ponto de destaque da atividade de interpretação constitucional é o fenômeno das mutações constitucionais, que são consentâneas com o método evolutivo de interpretação do Direito, o qual acompanha a alteração dos valores e dos fins que haviam inspirado a elaboração das disposições constitucionais.

21. Tratam-se de alterações não formais da Constituição, porque não previstas nos procedimentos de revisão típicos (como o seriam as emendas constitucionais).

22. As mutações constitucionais alteram o significado, o sentido e o alcance das disposições, ora por via da interpretação judicial, ora pelos costumes ou pela lei, pressupondo a mutabilidade social e a evolução dos valores políticos, econômicos, sociais e morais com o decurso do tempo.

23. Em processos como esse, deve-se atentar para os riscos de interpretações moralistas que acabem por violar o conteúdo da Constituição. Isso ocorre quando o intérprete imprime vetores da Moral comum ou de seus valores pessoais no ato exegético, em especial quando da interpretação dos princípios constitucionais, que possuem conteúdo muitas vezes vago e indeterminado.

24. Se essa atividade se revestir de conteúdo que inove originariamente na ordem jurídica, estaremos diante de assunção de postura ativista pelo Poder Judiciário.

25. Os riscos dessas construções residem na instabilidade jurídica que podem gerar ao sistema. Diferentemente das leis, cuja vinculação antecede o ato social, as decisões judiciais são sempre posteriores à conduta. Por isso, em sede de prescrições jurisdicionais criativas, não há como a sociedade se orientar de acordo com os padrões que serão eleitos como moralmente válidos pelos julgadores, visto que inexiste previsibilidade racional nas hipóteses em que não há disciplina prévia sobre o comportamento. Independentemente da eventual modulação de efeitos da decisão, o elemento "surpresa" não se afasta quando uma concepção moralista eleita pelo Judiciário a é imposta aos jurisdicionados. 
26. A análise do presente trabalho demanda a concepção da realidade brasileira no contexto posterior à CRFB-88. Portanto, pressupõe a existência de um Estado de Direito, com respeito às suas premissas, valendo a lei e a Constituição como fatores de limitação do arbítrio estatal.

27. Os Estados de Direito, diferentemente dos Estados meramente legalistas, assumem como centralidade a figura dos cidadãos.

28. As bases fundantes do Estado de Direito são as premissas da segurança jurídica, da separação de poderes, da limitação do poder por um sistema de freios e contrapesos, da garantia dos direitos fundamentais da pessoa humana e do regime democrático.

29. A limitação do poder, nesse contexto, é matéria que decorre dos postulados do Estado de Direito.

30. Outro imperativo intransponível ao Estado de Direito é a existência de Poder Judiciário forte, independente e autônomo. Mas, por óbvio, não arbitrário ou despótico.

31. A autonomia e a independência dos magistrados garantem aos cidadãos que suas liberdades fundamentais não serão limitadas a não ser nas hipóteses e na forma previstas em lei, sempre mediante justa atuação das autoridades judiciais.

32. Em relação à verificação prática dos limites constitucionais da função jurisdicional, podem ser identificados os seguintes vetores:

(a) O primeiro é o da utilização dos limites já normatizados acerca das ações diretas de inconstitucionalidade por omissão e dos mandados de injunção, para os casos de controle de constitucionalidade decorrente de omissões normativas inconstitucionais. Em verdade, mesmo nos casos de mandado de injunção, em que o Judiciário pode dar uma solução prática para a efetivação de direitos não concretizados por ausência de norma reguladora, não é possível a criação originária de regras. O que pode ser feito é o uso da função integradora da analogia, utilizando-se situações similares já disciplinadas em lei. Mas tal exercício de 
analogia não pode ferir direitos e garantias constitucionais, sob pena de, em prol da efetivação das pretensões de alguns, violarem-se cláusulas pétreas de outros;

(b) Em termos de políticas públicas, não pode o Poder Judiciário intervir na esfera de competência dos demais poderes, sob pena de catalisar debates e ações que são próprios do sistema político, potencializando o cenário de deficiências sistêmicas preexistente. Assim, jamais pode participar da formulação de tais matérias restritas ao cunho decisório político, sob pena de colocar em risco sua imparcialidade. Deve, assim, agir para fins de controle, sempre orientado pelas balizas constitucionais e pelos predicados do Estado de Direito já demonstrados. Até porque, $\mathrm{O}$ judiciário, no afã de intervir em políticas públicas, não raro adentra em searas sobre as quais não possui conhecimento e domínio adequado, visto que não fazem parte de suas atribuições típicas, estabelecendo juízos a partir de premissas erradas, com consequências contrárias ao interesse público.

(c) no exame da discricionariedade administrativa, não pode o Judiciário adentrar no mérito do ato, procedendo a avaliação sobre o juízo de conveniência e oportunidade que foi realizado pelo administrador público. Porém, pode e deve analisar os motivos do ato, e reconhecer sua eventual nulidade caso tenha sido praticado com desvio de poder, para atendimento de interesses escusos da autoridade executiva. Também é possível de análise judicial o atendimento das formalidades inerentes à produção do ato. Portanto, o que se efetiva é um controle de legalidade em sentido amplo.

(d) No que tange aos atos eminentemente políticos, não há possibilidade de controle jurisdicional, visto que dizem respeito a matérias estruturantes do próprio Estado, eleitas pelo constituinte e, por sua natureza, não judicializáveis.

(e) Já nos atos de chefia de Estado, pode haver controle judicial excepcional, apenas com vistas a evitar arbitrariedades. É o caso, por exemplo, da análise de conceitos vagos e indeterminados, como "grave comprometimento da ordem pública", ou "comoção grave de repercussão nacional”. Nessas hipóteses, pode o Judiciário declarar inconstitucional a atuação do Chefe de Estado que aja de maneira abusiva ou totalmente dissonante da 
razoabilidade. Seria o caso de controle em face de casos onde se pudesse verificar grande temeridade na atuação do Presidente da República.

(f) Os atos interna corporis, por seu turno, são sindicáveis quanto à sua forma, em termos de legalidade procedimental, mas também quanto ao seu conteúdo, em hipóteses excepcionais para se evitar teratologia.

(g) Reitere-se, ademais, que não produção de súmulas vinculantes, não pode o Judiciário inovar originariamente na ordem jurídica, devendo agir nos estritos limites da interpretação. Ou seja, tais súmulas são vetores (obrigatórios) de interpretação.

34. Por fim, não se deve esquecer que, quando o Poder Judiciário ultrapassa tais limites, está sujeito a reações sistêmicas ou populares, traduzidas em efeitos backlash, a teor das manifestações populares contrárias a magistrados, ou das proposições legislativas que tentam criminalizar a atividade interpretativa realizada pelo Judiciário, sempre que supostamente seja inconstitucional - valoração que, se realizada pelas esferas políticas de governo, por certo pode sofrer os influxos de tendências ideológicas autoritárias.

35. O Judiciário, por sua natureza, é inerte e só age quando é provocado. Por isso, não fosse a judicialização de inúmeras questões, decorrentes, não raro, da inação ou da ineficiente atuação das demais esferas de poder, como o Legislativo ou o Executivo, não seriam levadas à apreciação judicial questões de tamanho impacto social.

36. Destarte, os parâmetros de limitação aqui dispostos e verificados têm o condão de servir de orientação para a atuação do Poder Judiciário, mas só serão plenamente atendidos se partir das outras esferas de poder o comportamento ativo - também limitado constitucionalmente - que lhes é exigido.

37. Por isso, ao invés de criminalizar a conduta dos juízes, deveria ocupar-se o Legislativo de cumprir com primazia o seu mister de produção de leis - em especial nos casos em que, 
há muito, vem se omitindo inconstitucionalmente, convindo, inclusive, que se legisle para promover consequências jurídicas para tamanha inércia.

Eis, portanto, os parâmetros propostos para a melhoria do funcionamento das instituições e para o aprimoramento das atividades que expressam exercício de poder. 


\section{ÍNDICE DAS FONTES}

\section{REFERÊNCIAS BIBLIOGRÁFICAS}

ALEXY, Robert. Teoria dos direitos fundamentais. 2. ed. Trad. Virgílio Afonso da Silva. São Paulo: Malheiros, 2015.

ALMEIDA, Luiz Eduardo de. Direitos sociais e seus limites - Uma construção a partir das decisões do STF. Curitiba: Juruá, 2017.

ALVES, Alaôr Caffé. Estado e ideologia: aparência e realidade. São Paulo: Brasiliense, 1987.

ARAÚJO, Bruno. A Justiça no palco da media: a construção discursiva dos juízes do Mensalão em narrativas de Veja e Época. Animus. In: Revista Interamericana de Comunicação Midiática: 12/27/2018, Vol.17(35).

ARAUJO, Maria Paula Nascimento. Redemocratização e justiça de transição no Brasil. In: Studia Historica. Ediciones Universidad de Salamanca. Historia Contemporánea 33 (2015): $67-85$.

ARENDT, Hannah. The origins of totalitarianism. Cleveland e Nova York: Meridian Books, 1973.

ARISTÓTELES. Ética a Nicômacos. 3. ed. Brasília: Editora Universidade de Brasília, 2001.

ATIENZA, Manuel. As razões do Direito - teorias da argumentação jurídica. 3. ed. Trad. Maria Cristina Guimarães Cupertino. São Paulo: Landy, 2003.

ÁVILA, Humberto. Teoria dos princípios jurídicos: da definição à aplicação dos princípios jurídicos. 14. ed. São Paulo: Malheiros, 2013. 
BANDEIRA DE MELlO, Celso Antônio. Curso de Direito Administrativo. 33. ed. São Paulo: Malheiros, 2016.

. Discricionariedade e Controle Jurisdicional. 2. ed. São Paulo: Malheiros, 2003.

BARBOSA, Ruy. O Supremo Tribunal Federal na Constituição Brasileira. In: Escritos $e$ Discursos Seletos. Rio de Janeiro: Nova Aguilar S.A., 1997.

BARILE, Paolo. Instituzioni di diritto pubblico. 4. ed. Padova: CEDAM, 1982.

BARROS, Sérgio Resende de. Irretroatividade das leis. In: BEÇAK, Rubens (Org.); QUINTILIANO, Leonardo David; NIMER, Beatriz Lameira Carrico (Coord.). Princípios

Constitucionais: Contribuições à luz da obra de Sérgio Resende de Barros. Belo Horizonte: Arraes, 2018.

O Estado de Direito. In: BEÇAK, Rubens (Org.); QUINTILIANO, Leonardo David; NIMER, Beatriz Lameira Carrico (Coord.). Princípios Constitucionais: Contribuições à luz da obra de Sérgio Resende de Barros. Belo Horizonte: Arraes, 2018.

O Poder Judiciário e as políticas públicas: alguns parâmetros de atuação. In: BEÇAK, Rubens (Org.); QUINTILIANO, Leonardo David; NIMER, Beatriz Lameira Carrico (Coord.). Princípios Constitucionais: Contribuições à luz da obra de Sérgio Resende de Barros. Belo Horizonte: Arraes, 2018.

. Direitos humanos: paradoxo da civilização. Belo Horizonte: DelRey, 2003. . Contribuição dialética para o constitucionalismo. Campinas: Millennium, 2008.

BARROSO, Luís Roberto. Judicialização, ativismo judicial e legitimidade democrática. In: Revista do Tribunal Regional Eleitoral do Ceará, v. 5, n. 8, 2009.

Contramajoritário, representativo e iluminista: os papéis das supremas cortes e tribunais constitucionais nas democracias contemporâneas. In: Revista Interdisciplinar de Direito, Faculdade de Valença, v. 16, n. 1, jan./jun. 2018. 
O constitucionalismo democrático ou neoconstitucionalismo como ideologia vitoriosa do século XX. In: Revista Publicum, Rio de Janeiro, v. 4. Edição Comemorativa, 2018.

BEÇAK, Rubens. O Tribunal Constitucional e sua intervenção no processo político. In: Encontro Preparatório para o Congresso Nacional do Conpedi: Cidadania e a Efetividade dos Direitos, 17, 2008, Salvador. Anais, p. 2757-2772.

BEDAQUE, José Roberto dos Santos. Poderes instrutórios do juiz. 3. ed. São Paulo: Revista dos Tribunais, 2001.

BOBBIO, Norberto. A era dos direitos. Trad. Carlos Nelson Coutinho. Rio de Janeiro: Elsevier, 2004.

BLACK, Henry Campbell. Black's Law Dictionary. 6. ed. Minnesota: West Publishing Co., 1991.

CAetano, Marcelo. Manual de Ciência Política e Direito Constitucional - Tomo I. Coimbra: Almedina, 1995.

CAMPOS, Carlos Alexandre de Azevedo. Estado de coisas inconstitucional. Salvador: JusPodivm, 2016.

CAMPOS, Milton. Constituição e realidade. In: R. For., Rio de Janeiro, 187: 18-22, 1960.

CANOTILHO, José Joaquim Gomes. Direito constitucional e teoria da constituição. 7. ed. Coimbra: Almedina, 2003.

CAPPELLETTI, Mauro. Juízes legisladores? Porto Alegre: Sergio Antonio Fabris, 1993.

CARVALHO, José Murilo de. Cidadania no Brasil: o longo caminho. 18 ed. Rio de Janeiro: Civilização Brasileira, 2014.

CASTRO, Carlos Roberto Siqueira. Trinta anos da Constituição democrática de 1988. In: BEÇAK, Rubens; ALMEIDA PRADO, João Carlos Navarro de (Org.). Reflexões sobre os 30 anos da Constituição de 1988: Mutações e Reformas Constitucionais. Belo Horizonte: Arraes, 2018. 
CHAUÍ, Marilena. Conformismo e resistência. São Paulo: Brasiliense, 1993.

CINTRA, Antonio Carlos de Araújo; GRINOVER, Ada Pellegrini; DINAMARCO, Cândido Rangel. Teoria geral do processo. 25. ed. São Paulo: Malheiros, 2009.

CONTINENTINO, Marcelo Casseb. História do judicial review: O mito de Marbury. In: RIL, Brasília, a. 53, n. 209, jan./mar. 2016.

DANTAS, Bruno. Súmula vinculante: O STF entre a função uniformizadora e o reclamo por legitimação democrática. In: Revista de Informação Legislativa, Brasília, a. 45 n. 179, jul./set., 2008.

DAVID, René. Os grandes sistemas do direito contemporâneo. 2. ed. Trad. Hermínio A. Carvalho. São Paulo: Martins Fontes, 1993.

DIAS, Anielly Laena Azevedo. O espetáculo midiatizado do acontecimento jurídico: a cobertura telejornalística sobre a operação Lava Jato. In: Rizoma, Santa Cruz do Sul, v. 6, n. 2, dezembro, 2018.

DINIZ, Maria Helena. Curso de Direito Civil Brasileiro. v. 1. Teoria Geral do Direito Civil. 25. ed. São Paulo: Saraiva, 2008.

DI PIETRO, Maria Sylvia Zanella. Direito Administrativo. 23. ed. São Paulo: Atlas, 2010. . Discricionariedade técnica e discricionariedade administrativa. In: Revista Brasileira de Direito Público - RBDP. Belo Horizonte: Fórum, 17:75-96, abr./jun. 2007.

DWORKIN, Ronald. Freendom's law: the moral Reading of the American Constitution. Oxford: Oxford University Press, 1996. . Taking rights seriously. 2. ed. Londres: Duckworth, 1978.

FERRAZ, Anna Cândida da Cunha. Processos informais de mudança da Constituição. 2. ed. Osasco: EDIFIEO, 2015.

FERRAZ JR., Tercio Sampaio. Introdução ao estudo do Direito. 4. ed. São Paulo: Atlas, 2007. 
FERREIRA, Luis Pinto. Da Constituição. 2. ed. Rio de Janeiro: José Konfino, 1956.

FERREIRA FILHO, Manoel Gonçalves. Curso de Direito Constitucional. 31. ed. São Paulo: Saraiva, 2005.

Estado de direito e constituição. São Paulo: Saraiva, 1988.

GARCÍA, Enrique Alonso. La interpretación de la constitución. Madrid: Centro de Estudios Constitucionales, 1984.

GLENN, H. Patrick. Legal traditions of the world. 2. ed. Oxford: Oxford University Press, 2004.

GUASTINI, Riccardo. Estudios de teoría constitucional. México: Doctrina Jurídica Contemporánea, 2001.

HAURIOU, Maurice. Précis de droit administratif et de droit public. 11 ${ }^{\mathrm{a}}$ Edição. Paris: Recueil, 1927.

HESSE, Konrad. A força normativa da Constituição. Porto Alegre: Sérgio Antônio Fabris, 1991.

HÖFFE, Otfried. Derecho intercultural. Trad. Rafael Sevilla. Barcelona: Gedisa, 2000.

HOLMES, Stephen; SUNSTEIN, Cass R. The cost of rights: why liberty depends on taxes. Nova York: W.W. Norton \& Company, 2000.

JELLINEK, Georg. Teoría general del Estado. Trad. para o espanhol de Fernando de Los Ríos. México: Fondo de Cultura Económica, 2000.

KELSEN, Hans. Teoria pura do Direito. São Paulo: Martins Fontes, 1985.

KOOPMANS, Tim. Legislature and Judiciary: Present Trends. New perspectives for a common law of Europe/Nouvelles perspectives d'un droit commun de l'europe. Florença: Leiden, 1978. 
LAZZARINI, Álvaro. Magistratura: deontologia, função e poderes do juiz. Caderno de Doutrina e Jurisprudência da Ematra XV, v.1, n.4, jul./ago. 2005.

LEAL, Victor Nunes. Passado e futuro da súmula do STF. In: Revista de Direito Administrativo. n. 145. jul./set. 1981. . Problemas de Direito Público. São Paulo: Forense, 1960.

LESSA, Francesca; OLSEN, Tricia D.; PAYNE, Leigh A.; PEREIRA, Gabriel; REITER, Andrew G. Overcoming impunity: pathways to accountability in Latin America. In: The International Journal of Transitional Justice, v. 8, 75-98, 2014.

LINARES QUINTANA, Segundo V. La constitucion interpretada. Buenos Aires: Depalma, 1960.

LOCKE, John. Segundo tratado sobre o governo civil e outros escritos. Petrópolis: Vozes, 1994.

MAGAlHÃES NORONHA, E. Direito Penal. 1. v. São Paulo: Saraiva, 1974.

MALBERG, R. Carré de. Teoría general del Estado. Trad. para o espanhol de José Lión Depetre. México: Fondo de Cultura Económica, 2001.

MANCUSO, Rodolfo de Camargo. Sistema brasileiro de precedentes. 2. ed. São Paulo: Revista dos Tribunais, 2016.

Divergência jurisprudencial e súmula vinculante. 3. ed. São Paulo: Revista dos Tribunais, 2007.

MASTERMAN, Roger. The separation of Powers in the contemporary constitution: Judicial competence and independence in the United Kingdom. Cambridge: Cambridge University Press, 2011.

MEIRELLES, Hely Lopes. Direito Administrativo Brasileiro. 34. ed. São Paulo: Malheiros, 2008. 
MENDES, Gilmar Ferreira. Controle abstrato de constitucionalidade: ADI, ADC e ADO. São Paulo: Saraiva, 2002.

MERRYMAN, John Henry. The civil law tradition: an introduction to the legal systems of Western Europe and Latin America. 2. ed. Standford: Standford University Press, 1985.

MEZAROBBA, Glenda. Between reparations, half truths and impunity: the difficult break with the legacy of the dictatorship in Brazil. In: International Journal of Human Rights, v. 7, n. 13 , dec-2010.

MIRANDA, Jorge. Manual de Direito Constitucional. Coimbra: Coimbra Editora, 2001.

MONTESQUIEU, Charles-Louis de Secondat, Barão de la Brède e de. O espírito das leis. Trad. Cristina Murachco. São Paulo: Martins Fontes, 2000.

MONTORO, André Franco. Introdução à Ciência do Direito. 26. ed. São Paulo: Revista dos Tribunais, 2005.

MORAIS, Carlos Blanco de. O sistema político no contexto da erosão da democracia representativa. Coimbra: Almedina, 2017.

MORE, Thomas. Utopia. Livro I. New Haven \& London: Yale University Press, 2014.

MUSSETTI, Rodrigo Andreotti. O nepotismo legal e moral nos cargos em comissão da administração pública. Boletim de Direito Administrativo - BDA, São Paulo, jan./2014.

NELSON, William E. Marbury v. Madison: The Origins and Legacy of Judicial Review. 2. ed. revista e expandida. Lawrence: University Press of Kansas, 2018.

NERY JUNIOR, Nelson; NERY, Rosa Maria de Andrade. Comentários ao Código de Processo Civil. São Paulo: Revista dos Tribunais, 2015.

. Código de Processo Civil comentado e legislação processual civil extravagante em vigor. São Paulo: Revista dos Tribunais, 2002.

NINO, Carlos Santiago. Introducción al análisis del Derecho. Buenos Aires: Astrea, 1980. 
NOVAIS, Jorge Reis. As restrições aos direitos fundamentais não expressamente autorizadas pela Constituição. 2. ed. Coimbra: Coimbra Editora, 2010.

- Direitos sociais: teoria jurídica dos direitos sociais enquanto direitos fundamentais. Coimbra: Coimbra Editora, 2010.

O'CONNOR, Vivienne. Common law and civil law traditions. In: INPROL - International Network to Promote the Rule of Law, mar./2012.

PEREIRA, Anthony. Political (In)Justice: Authoritarianism and the Rule of Law in Brazil, Chile, and Argentina. Pittsburgh, PA: Pittsburgh University Press, 2005.

PINTO, Sobral. Lições de liberdade: os direitos do homem no Brasil. Belo Horizonte: Comunicação, 1977.

PIRES, Luis Manuel Fonseca. Controle judicial da discricionariedade administrativa: dos conceitos jurídicos indeterminados às políticas públicas. Belo Horizonte: Fórum, 2017.

PONTE, Antonio Carlos da. Crimes eleitorais. São Paulo: Saraiva, 2008.

POWER, Timothy J. The Brazilian Military Regime of 1964-1985: Legacies for Contemporary Democracy. In: Iberoamericana 16.62 (2016): 13-26.

QUINTILIANO, Leonardo David. Direitos sociais e vinculação do legislador: as reformas previdenciárias e seus limites constitucionais no Estado Social e de Direito. Rio de Janeiro: Lumen Juris, 2019.

RADCLIFFE, Cyril John. Not in feather beds: some collected papers. Londres: H. Hamilton, 1968.

RAMOS, Elival da Silva. Ativismo judicial - Parâmetros dogmáticos. São Paulo: Saraiva, 2010.

. Controle de Constitucionalidade no Brasil: perspectivas de evolução. São Paulo: Saraiva, 2010.

REALE, Miguel. Lições preliminares de Direito. São Paulo: Saraiva, 2007. 
ROCHA, José de Albuquerque. Teoria Geral do Processo. São Paulo: Malheiros, 1996.

SANTOS, Fabiano; SZWAKO, José. Da ruptura à reconstrução democrática no Brasil. In: Saúde Debate: Rio de Janeiro, v. 40, n. especial (dez/2016): 114-121.

SCHÄEFER, Jairo Gilberto. O problema da fiscalização da constitucionalidade dos atos políticos em geral. In: Interesse Público, Porto Alegre: Notadez, 35:79-97, jan./fev. 2006.

SCHNEIDER, Hans Peter. Democracia e Constituición. Madrid: Centro de Estudios Constitucionales, 1991.

SILVA, José Afonso da. Constituição e segurança jurídica. In ROCHA, Cármen Lúcia Antunes (Coord.). Constituição e segurança jurídica: direito adquirido, ato jurídico perfeito e coisa julgada. Belo Horizonte: Fórum, 2009.

Curso de Direito Constitucional Positivo. 30. ed. São Paulo: Malheiros, 2008.

SOUZA, Motauri Ciocchetti de. Ministério Público e o princípio da obrigatoriedade - Ação Civil Pública - Ação Penal Pública. São Paulo: Método, 2007.

TAVARES, André Ramos. Tratado da arguição de preceito fundamental. São Paulo: Saraiva, 2001.

TORELLY, Marcelo. Assessing a Late Truth Commission: Challenges and Achievements of the Brazilian National Truth Commission. In: International Journal of Transitional Justice, 2018, 12, 194-215.

WEBER, Max. Economia y sociedade. México: Fondo de Cultura Económica, 1964.

WELTER, Henri. Le contrôle jurisdictionnel de la moralité administrative. Paris: Recueil, 1929. 


\section{TESES E DISSERTAÇÕES REFERIDAS}

GUZ, Manoella. Bem jurídico penal difuso e coletivo. 2010. 205 f. Dissertação (Mestrado em Direito). Faculdade de Direito da Pontifícia Universidade Católica de São Paulo, São Paulo, 2010.

RAMOS, Luciana de Oliveira. O Controle de Constitucionalidade por Omissão no Supremo Tribunal Federal: Análise dos Casos de Omissão Legislativa nos Vinte e Um Anos da Constituição. 2010. 135 f. Dissertação (Mestrado em Ciência Política). Faculdade de Filosofia, Letras e Ciências Humanas da Universidade de São Paulo, São Paulo, 2010.

SOUZA, Luiz Herique Boselli de. A correlação da efetividade das normas constitucionais com o suprimento das omissões normativas. 2010. 226 f. Tese (Doutorado em Direito). Faculdade de Direito da Universidade de São Paulo, São Paulo, 2010.

\section{REFERÊNCIAS A ENDEREÇOS ELETRÔNICOS}

BARROS, Sérgio Resende de. Impeachment. Disponível em: <http://www.srbarros.com.br/pt/-i-impeachment--i-.cont>. Acesso em 14 fev. 2018.

CÂMARA DOS DEPUTADOS. Ficha de tramitação do PL 4754/2016. Disponível em: $<$ https://www.camara.leg.br/proposicoesWeb/fichadetramitacao?idProposicao=2079700>. Acesso em 20 jan. 2020.

COMISSÃO DE CONSTITUIÇÃO E JUSTIÇA E DE CIDADANIA DA CÂMARA DOS DEPUTADOS. Parecer sobre o PL 4754/2016. Gabinete da Deputada Relatora Chris Tonietto - $\quad$ PSL-RJ. Disponível em: <https://www.camara.leg.br/proposicoesWeb/prop_mostrarintegra?codteor=1769130\&file name $=$ Tramitacao-PL+4754/2016>. Acesso em 20 jan. 2020.

McBRIDE, Alex. Dred Scott v. Sandford (1857). In Supreme Court History - The first hundred years. Landmark cases. Disponível em: 
<https://www.thirteen.org/wnet/supremecourt/antebellum/landmark_dred.html>. Acesso em 02 out. 2018.

MINISTÉRIO DOS DIREITOS HUMANOS. Secretaria de Cidadania. Violência LGBTFóbicas no Brasil: dados da violência. Brasil, 2018. Disponível em: <https://www.mdh.gov.br/biblioteca/consultorias/lgbt/violencia-lgbtfobicas-no-brasildados-da-violencia>. Acesso em 12 nov. 2019.

MINISTÉRIO PÚBLICO FEDERAL. Operação Lava Jato. Disponível em: <http://www.mpf.mp.br/grandes-casos/lava-jato>. Acesso em 08 dez. 2019.

MOVIMENTO BRASIL LIVRE. Lista completa de objetivos do MBL. Disponível em: <http://mbl.org.br/wordpress/wp-content/uploads/2017/05/propostas-mbl.pdf>. Acesso em 04 dez. 2019.

PERTENCE, José Paulo Sepúlveda. Relatório do Projeto de Lei da Anistia. Senado Federal do Brasil, 15 de agosto de 1979, p. 5-6. Disponível em: <https://www.conjur.com.br/dl/parecer_oab_anistia_79.pdf>. Acesso em 03 dez. 2019.

SCHIBUOLA, Tatiana. Entrevista: quem é Rosangela Moro? Revista Cláudia. São Paulo: 02 mar. 2017. Disponível em: <https://claudia.abril.com.br/noticias/entrevista-quem-erosangela-moro/>. Acesso em 10 dez. 2019.

TV JUSTIÇA. STF. Disponível em: <http://www.tvjustica.jus.br/>. Acesso em 06 dez. 2019.

UNITED NATIONS. Guidance Note of the Secretary-General: United Nations Approach to Transitional Justice, março de 2010. Disponível em: <http://www.unrol.org/files/TJ_Guidance_Note_March_2010FINAL.pdf>. Acesso em 20 out. 2019.

UOL POLÍTICA. Grife lança camisa com frase "In Moro we trust" a R\$ 198. São Paulo, 26 fev. 2016. Disponível em: <https://noticias.uol.com.br/politica/ultimasnoticias/2016/02/26/grife-lanca-camisa-com-frase-in-moro-we-trust-a-r198.htm?cmpid=copiaecolahttps://noticias.uol.com.br/politica/ultimasnoticias/2016/02/26/grife-lanca-camisa-com-frase-in-moro-we-trust-a-r-198.htm>. Acesso em 09 dez. 2019. 
UOL POLÍTICA. Apoio a fechar Congresso e STF avança entre a direita, mostra pesquisa. São Paulo, 10 jun. 2019. Disponível em: <https://noticias.uol.com.br/politica/ultimasnoticias/2019/06/10/apoio-a-fechar-congresso-e-stf-avanca-entre-a-direita-mostrapesquisa.htm>. Acesso em 10 jun. 2019.

\section{REFERÊNCIAS A MATÉRIAS JORNALÍSTICAS IMPRESSAS}

GLOBO. Eles merecem ganhar tanto? Revista Época. Rio de Janeiro: 27 ago. 2012

FARIA, José Eduardo. Políticos e juízes, entre o destino e a tragédia. O Estado de São Paulo. São Paulo, 25 jun. 2018. Espaço Aberto, p. A2.

MARQUES, Hugo; DINIZ, Laura. O menino pobre que mudou o Brasil. Revista Veja. São Paulo, 10 out. 2012. 